\title{
A choice and inevitability framework in strategic management: Empirical evidence of its real life existence
}

\author{
Daniele Tumidei*, Constantinos Alexiou** and Michael Bourne***
}

\begin{abstract}
In the context of strategic management, strategic choice and determinism are presented as two distinct planning approaches. When treated as two distinct variables, they are responsible for the creation of a framework of analysis, in which it is possible to identify the four different human agency philosophical ontological perspectives, of determinism, hard incompatibilism, libertarianism and compatibilism, each perspective characterized by different amounts of strategic choice and determinism. By drawing on the theoretical context of the aforementioned perspectives, we provide empirical evidence of their real-life existence. The strategic framework not only reduces theoretical fragmentation, but also provides a link between the philosophical debate on free will/determinism and strategic management and can help to reduce uncertainty in planning.
\end{abstract}

Keywords Determinism • Free will $\bullet$ Strategic choice $\bullet$ Strategic decision making $\bullet$ Human agency $\bullet$ Panel data

JEL codes: L1; C23

*Cranfield University

School of Management

Bedfordshire, MK43 0AL, UK

Email: daniele.tumidei@cranfield.ac.uk

\section{**Corresponding author}

Cranfield University

School of Management

Bedfordshire, MK43 0AL, UK

Email: constantinos.alexiou@cranfield.ac.uk

ORCID ID: https://orcid.org/0000-0002-9481-3066

***Cranfield University

School of Management

Bedfordshire, MK43 0AL, UK

Email: $\underline{\text { m.bourne@,cranfield.ac.uk }}$

\section{Acknowledgements}

We are grateful to three anonymous reviewers and the editor of the journal for their comments which improved this article. The usual disclaimer applies. 


\title{
A choice and inevitability framework in strategic management: Empirical evidence of its real-life existence
}

\begin{abstract}
In the context of strategic management, strategic choice and determinism are presented as two distinct planning approaches. When treated as two distinct variables, they are responsible for the creation of a framework of analysis, in which it is possible to identify the four different human agency philosophical ontological perspectives, of determinism, hard incompatibilism, libertarianism and compatibilism, each perspective characterized by different amounts of strategic choice and determinism. By drawing on the theoretical context of the aforementioned perspectives, we provide empirical evidence of their real-life existence. The strategic framework not only reduces theoretical fragmentation, but also provides a link between the philosophical debate on free will/determinism and strategic management and can help to reduce uncertainty in planning.
\end{abstract}

Keywords Determinism $\bullet$ Free will $\bullet$ Strategic choice $\bullet$ Strategic decision making $\bullet$ Human agency $\bullet$ Panel data JEL codes: L1; C23

\section{Introduction}

If we consider organizational management, we quickly realize that, although there are many theories that attempt to explain how management's choices can affect organizational performance, the quest for a comprehensive theory of management (Bourgeois 1984; De Rond and Thietart 2007; Joullié 2018), which began in the first decades of the $20^{\text {th }}$ century, is far from over.

This paper sheds some light, both at a theoretical and at an empirical level, on why existing management theories are both so fragmented and so limited in their validity, and why it proves so elusive to identify a single theory of management, and presents the reasons for the difficulties in framing management-related dynamics, thus helping to increase management's decision reliability and predictability.

Our physical world appears both undetermined on the smallest scale, as posited by quantum mechanics - see for instance Heisenberg (1926) - and determined and orderly where the traditional laws of physics are manifested. In a similar fashion, our social reality may appear totally undetermined - when we look at the erratic movements that take place from time to time on the stock exchange - or determined - as in when we buy and sell government bonds or are able to regularly buy groceries in the supermarket across the road. In the above contexts, the difference between what is determined and what is undetermined largely depends on what we are looking at and on how we look at it.

Although these premises may, on the one hand, be looked upon as discouraging factors in finding an explanation for such contrasting aspects of our everyday lives, on the other hand, the philosophical study of what is determined or undetermined and of the role that free will may play in it may have a profound impact on the way we see our world and the way we behave and make choices in our everyday lives.

This paper aims to highlight the contrasting philosophical stances that originate from free will and determinism in mapping the human agent's operational space, as well as to provide a framework that will be able to be used effectively in the realm of strategic management. In this direction, we provide for the first time novel empirical evidence on the real-life existence of the ontological perspectives in which it is possible to position each organization, by identifying how much the organization relies on strategic choice and/or determinism.

In the first part of the paper, we highlight the links between human agency, free will and determinism, and strategic management choices and socio-economic determinism. We then proceed to develop the strategic choice determinism framework, which is composed of four different perspectives, and describe the features of each of them. Next, we engage in the empirical analysis in the context of the real-life existence of this framework. A discussion of the results and the respective theoretical and empirical implications of the strategic choice determinism framework takes place, after which we provide some concluding remarks.

\section{Theoretical background}

The strategic management literature presents us with two main approaches to planning: determinism and strategic choice (Bourgeois 1984; Thompson 1967; Child 1972). It therefore appears important that we look for a single framework offering the possibility of linking these two opposing approaches to planning and the theories they generate.

Determinism, which consists of applying the laws ruling the external environment to predict external environment dynamics and organizational performance, produces theories, frameworks or laws such as industry structure, technological processes, size and ownership, product life cycle, market share, power of supplier and buyers, and mobility barriers (Bourgeois 1984). According to Bourgeois (1984), deterministic planning also 
consists of a reaction to contingent organizational, external-environment conditions; as a result, managers' behaviour is explained through contingency theory.

Similarly, strategic choice can be used, in contrast to deterministic planning, to influence and shape the external environment by setting strategic goals, choosing a specific field of activity, and selecting both a technology and an organizational structure (Bourgeois 1984; Child 1972).

Table 1 summarizes what distinguishes deterministic from strategic-choice-based planning.

Table 1 Differences between deterministic and strategic-choice-based planning

\begin{tabular}{|c|c|c|}
\hline & Description of planning approach & Features and links to the literature \\
\hline $\begin{array}{l}\text { Deterministic } \\
\text { (user- } \\
\text { responder) }\end{array}$ & $\begin{array}{l}\text { - Social reality actors make choices from the } \\
\text { causal background, following existing rules } \\
\text { and preset behavioural patterns, to foresee and } \\
\text { reach their goals (De Rond and Thietart 2007). } \\
\text { Actions are carried out as a reaction to some } \\
\text { external environment (causal environment) } \\
\text { conditions, complying with existing laws and } \\
\text { regulations. } \\
\text { Decision making makes use of statistics, and } \\
\text { utilizes existing technology, infrastructure, } \\
\text { brands, resources etc. }\end{array}$ & $\begin{array}{ll}\text { - } & \text { Easier to foresee or determine a } \\
\text { course of action } \\
\text { - } & \text { Constrained by what exists } \\
\text { (Bourgeois 1984) } \\
\text { - } \quad \text { More likely to face competition } \\
\text { - Management control system } \\
\text { through diagnostic control } \\
\text { (Simons 1991) } \\
\text { - Risk management based on } \\
\text { contingencies creation. ISO } \\
\text { 31000 (2009) }\end{array}$ \\
\hline $\begin{array}{l}\text { Strategic } \\
\text { choice } \\
\text { (creator- } \\
\text { modifier) }\end{array}$ & $\begin{array}{l}\text { - Social reality actors act out of pre-set schemes, } \\
\text { in such a way as to influence and mould the } \\
\text { external environment by creating new laws, } \\
\text { regulations, new technology, new brands, } \\
\text { resources etc. } \\
\text { Social actors modify or build something new } \\
\text { starting from what exists. }\end{array}$ & 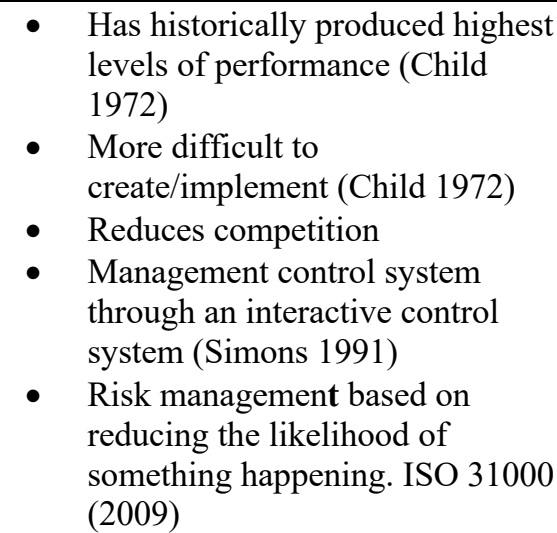 \\
\hline
\end{tabular}

The dichotomy between deterministic and strategic-choice-based planning, described above, was overcome by De Rond and Thietart's (2007) view of strategy creation, according to which determinism, choice and chance have a clearly defined, synergic and non-conflicting role in strategy creation.

According to De Rond and Thietart (2007), social actors operate within what exists or what has been socially constructed up to the present day, or the causal background, consisting of contextual variables, which include agent-specific states or manager idiosyncrasies (habit, know-how, experience, age, education, ideology and systemic rationality), as well as more general social states (institutions, social structures, the properties of markets and industries, the evolving state of technology and the economy, the features of the social world).

Strategy is produced, as shown in Figure 1, by managers' choices, for which they become responsible, against the causal background, with the interplay of chance (De Rond and Thietart 2007).

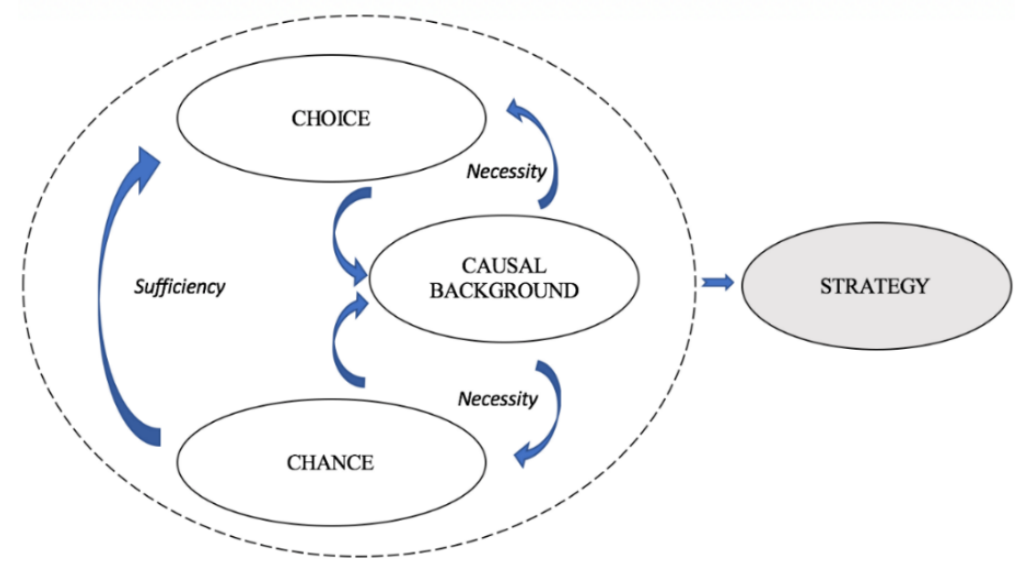

Fig. 1 The causal background within which choice and chance produce strategy 
Within this context, causation can be referred to as the managers' choices as opposed to the mechanistic causality principle known in the natural world. Empirical evidence of the existence the causal background is provided by Pucheta-Martínez, Gallego-Álvarez (2019), Jost (2013), Shwairef et al. (2019) and Yoon et al. (2016), according to whom managers' idiosyncrasies and board composition influence boards' behaviour and ultimately organizational performance.

\subsection{Human Agency, Strategic Choice and Determinism}

To take a step forward in understanding the meaning and implications of strategic choice, determinism and chance for strategic management, and identify a framework that could more comprehensively link the two planning approaches, it is important to analyse the human agency field and the perspectives generated by all the possible combinations of the two philosophical principles of free will and determinism, as shown in Figure 2.

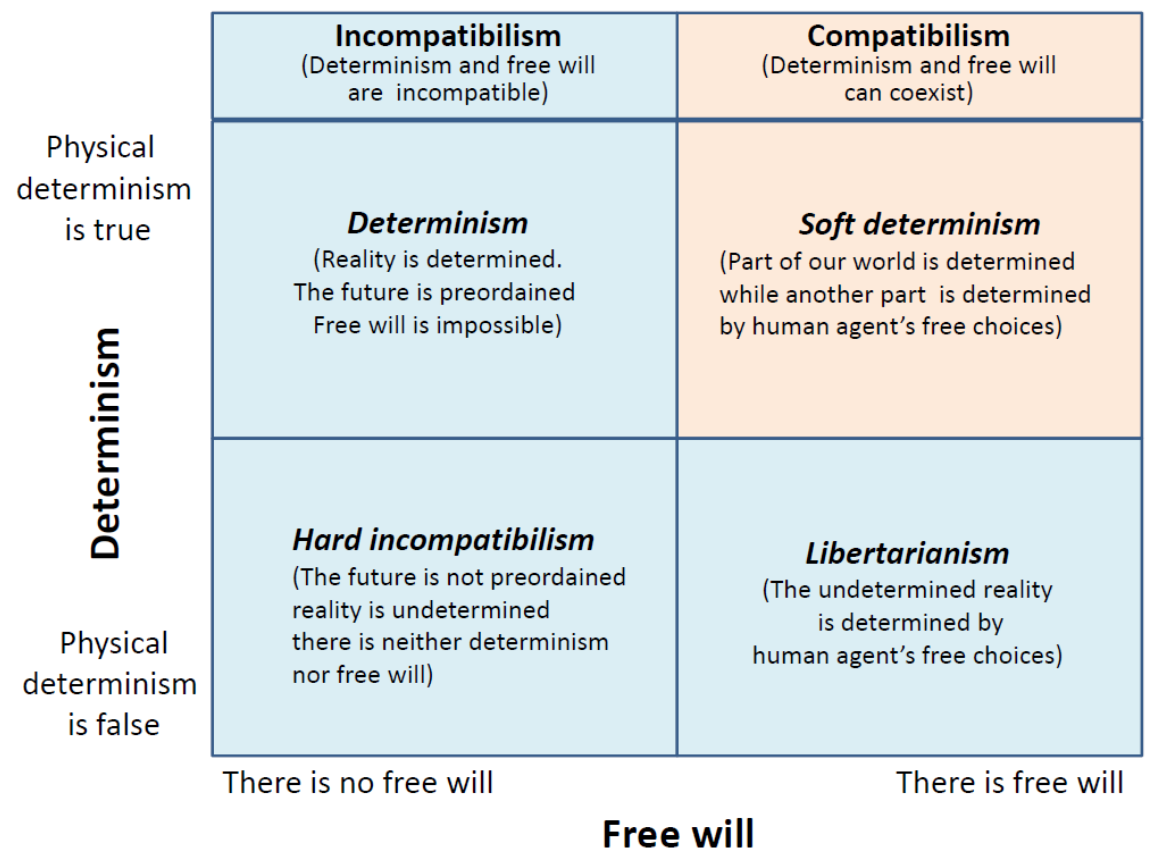

Fig. 2 Perspectives generated by free will and determinism

It can be noted that the combination of free will and determinism produces two distinct conditions, one in which determinism or free will or both are not true and therefore are incompatible, and another in which both determinism and free will are true and possible and are, therefore, compatible.

\subsection{Incompatibilism and compatibilism}

Within incompatibilism, there is a dichotomy between free will and determinism, which generates three possible views: (a) determinism, in which only determinism exists and it is denied that any free will exists, (b) hard incompatibilism, which denies both that the physical world is determined and that free will exists, and (c) libertarianism, ${ }^{1}$ which denies that the universe is deterministic and states that only free will exists (Stanford Encyclopedia of Philosophy(a), 2018).

Opposite to the incompatibilist stance, there is compatibilism (or soft determinism), which is the belief that determinism and free will are compatible conditions and that it is coherent to believe that both conditions can coexist (Stanford Encyclopedia of Philosophy(b), 2018; De Rond and Thietart 2007).

The respective distinctive features of these philosophical perspectives can, at first, help explain different kinds of human agent causation and responsibility, which ultimately influence the way the human agent behaves. An agent's behaviour, when he/she is looked at as a manager, will help to understand causation and responsibility, which respectively explain and affect managerial behaviour, and ultimately strategy creation.

\footnotetext{
${ }^{1}$ Libertarianism also describes a collection of political philosophies and movements that uphold liberty as a core principle. Although free will and independence of judgement are shared with the economic and management libertarianism to which this paper refers, the former political libertarianism is not directly related to the arguments of this paper.
} 
In the strategic management literature, Astley and Van de Ven (1983) and Hrebiniak and Joyce (1985) respectively present a framework of the main organizational theories and environmental adaptation, according to which organizations adapt to the external environment, according to the different uses they make of strategic choice and determinism. Although each of these frameworks is composed of four perspectives, which share most of the features of the four human agency philosophical perspectives of determinism, hard incompatibilism, libertarianism and compatibilism, these authors did not highlight the existence of a link between strategic management and human agency.

Table 2 presents the common features, which suggest a connection, between free will and determinism in human agency, and strategic choice and socio-economic determinism in organizational theory and organizational adaptation.

Table 2 Common features between human agency, organizational theory and organizational adaptation.

\begin{tabular}{|c|c|c|c|}
\hline $\begin{array}{c}\text { Perspective } \\
\text { features }\end{array}$ & Human agency & $\begin{array}{c}\text { Organizational theory } \\
\text { Astley \& Van de Ven (1983) }\end{array}$ & $\begin{array}{c}\text { Organizational adaptation } \\
\text { Hrebiniak \& Joyce (1985) }\end{array}$ \\
\hline Name: & Determinism & System structural & Environmental selection \\
\hline Choice & No choice available & $\begin{array}{l}\text { Determined, constrained and } \\
\text { adaptive }\end{array}$ & Minimum choice \\
\hline Features/Theories & Reality is determined & $\begin{array}{l}\text { System theory, structural } \\
\text { functionalism and } \\
\text { contingency theory }\end{array}$ & $\begin{array}{l}\text { Adaptation or selection out } \\
\text { Level of innovation: low }\end{array}$ \\
\hline Responsibility & No responsibility & $\begin{array}{l}\text { Limited to the ability to know } \\
\text { or respond to the environment } \\
\text { dynamics }\end{array}$ & $\begin{array}{l}\text { Limited to the ability to } \\
\text { know or respond to the } \\
\text { environment dynamics }\end{array}$ \\
\hline $\begin{array}{l}\text { Power and } \\
\text { control }\end{array}$ & $\begin{array}{l}\text { The agent has no } \\
\text { power }\end{array}$ & Manager role is reactive & \\
\hline Name: & Hard incompatibilism & Natural selection & Undifferentiated choice \\
\hline Choice: & No choice available & Random, natural or economic & Incremental choice \\
\hline Features & $\begin{array}{l}\text { Reality is } \\
\text { undetermined }\end{array}$ & $\begin{array}{l}\text { Population ecology, industrial } \\
\text { economics, economic history }\end{array}$ & $\begin{array}{l}\text { Adaptation by chance } \\
\text { Level of innovation is low }\end{array}$ \\
\hline Responsibility & No responsibility & Little or no responsibility & Little or no responsibility \\
\hline $\begin{array}{l}\text { Power and } \\
\text { control }\end{array}$ & $\begin{array}{l}\text { The agent has no } \\
\text { power }\end{array}$ & Manager role: inactive & \\
\hline Name: & Libertarianism & Strategic choice & Strategic choice \\
\hline Choice: & Maximum choice & $\begin{array}{l}\text { Constructed, autonomous and } \\
\text { enacted }\end{array}$ & Maximum choice \\
\hline Features & $\begin{array}{l}\text { Reality is } \\
\text { undetermined }\end{array}$ & $\begin{array}{l}\text { Action theory, contemporary } \\
\text { decision theory, strategic } \\
\text { management }\end{array}$ & $\begin{array}{l}\text { Adaptation by design } \\
\text { Level of innovation is high }\end{array}$ \\
\hline Responsibility & $\begin{array}{l}\text { Maximum } \\
\text { responsibility }\end{array}$ & $\begin{array}{l}\text { Responsibility to influence } \\
\text { and change the organizational } \\
\text { context }\end{array}$ & Total responsibility \\
\hline $\begin{array}{l}\text { Power and } \\
\text { control }\end{array}$ & The agent has power & Manager role is proactive & \\
\hline Name: & Compatibilism & Collective action & Differentiation or focus \\
\hline Choice: & Some choice & $\begin{array}{l}\text { Responsible, collectively } \\
\text { constructed }\end{array}$ & Differentiated choice \\
\hline Features & $\begin{array}{l}\text { Reality is partly } \\
\text { determined and partly } \\
\text { undetermined }\end{array}$ & $\begin{array}{l}\text { Human ecology, political } \\
\text { economy, pluralism }\end{array}$ & $\begin{array}{l}\text { Adaptation with constraints } \\
\text { Level of innovation is } \\
\text { medium }\end{array}$ \\
\hline Responsibility & Some responsibility & $\begin{array}{l}\text { Responsibility to both know } \\
\text { and react to the organizational } \\
\text { context and alter it }\end{array}$ & $\begin{array}{l}\text { Responsibility to both know } \\
\text { and react to the } \\
\text { organizational context and } \\
\text { alter it }\end{array}$ \\
\hline $\begin{array}{l}\text { Power and } \\
\text { control }\end{array}$ & $\begin{array}{l}\text { The agent has some } \\
\text { power }\end{array}$ & Manager role is interactive & \\
\hline
\end{tabular}


In this context, essential elements to the understanding of the dynamics, which explain how organizations originate and move from one perspective to another, and the mechanisms which make companies behave differently within any of the four different previously presented perspectives, can be traced in the theories of organizational path dependence, of Sydow et al. (2009), and that of imprinting, of Marquis and Tilcsik (2013). More specifically, path dependence is the outcome of one or more random events which occur during the organizational life. These events create a path onto which organizations lock in, and on which they become dependent in order to produce performance, hence constantly reducing the importance of management.

Path dependence occurs in three phases (see Figure 3): During Phase I, the organization is presented with many choices and options; in Phase II, an organizational path emerges thanks to a critical event, which catalyses organizational activities towards a specific direction or favour of choice; in Phase III, the organization locks onto the path and becomes dependent on it in order to produce performance.

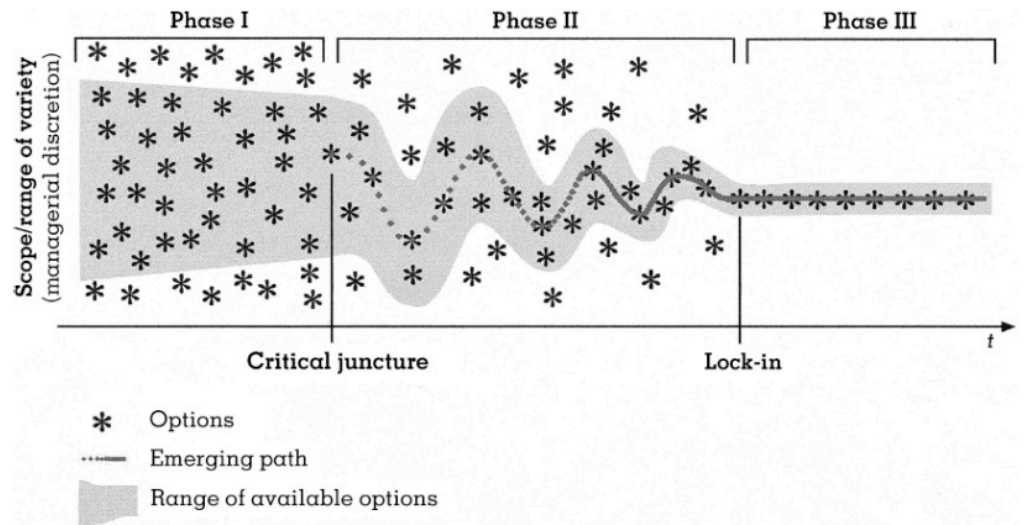

Fig. 3 The constitution of an organizational path (Sydow et al. 2009)

Although Sydow et al. (2009) mainly focus on the particular organizational path that is activated by a random event and becomes determined after the lock-in phase, in their paper they also acknowledge that the "path can actually be broken" (p.703) as well as that "the path can be deliberately brought about" (p.705) in addition to being originated by a random event.

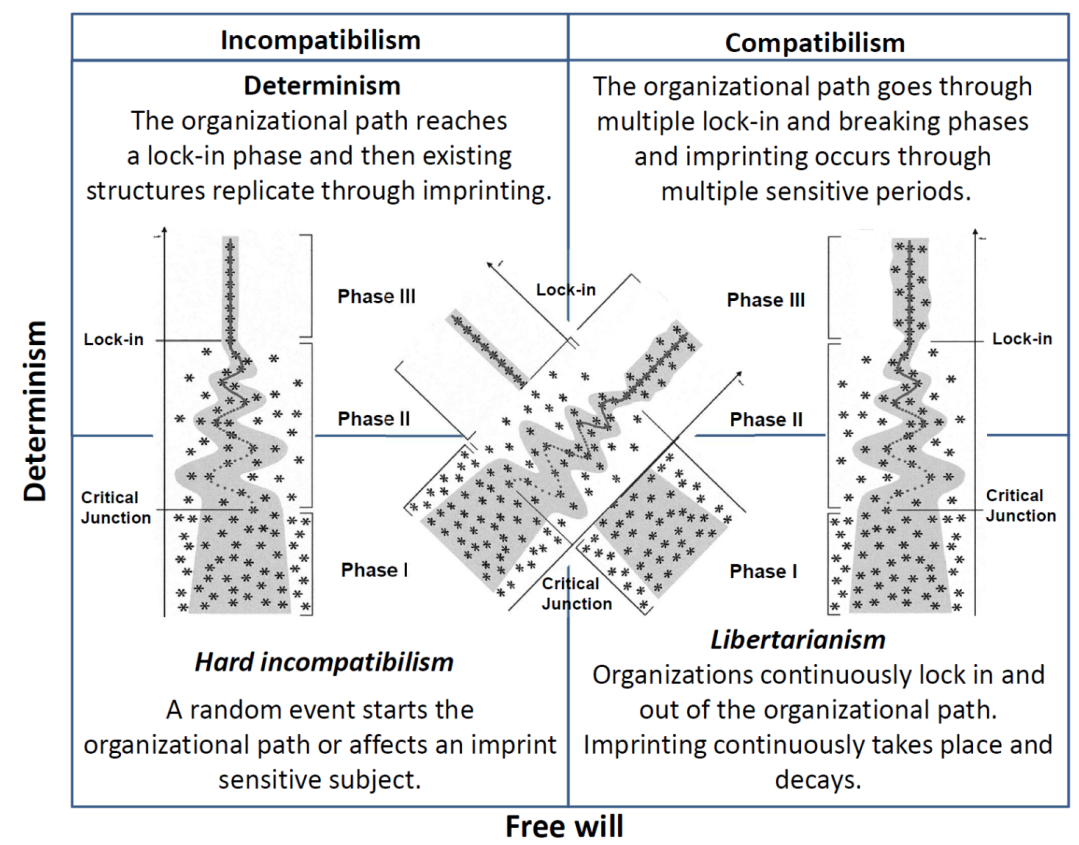

Fig. 4 Possible organizational paths and imprinting cases in the human agency perspectives

Figure 4 illustrates how paths can be generated, according to the organizational path theory, and move from one to another of the four different human agency perspectives. 
Marquis and Tilcsik's $(2013)^{2}$ imprinting consists of the exposure of the "focal entity" to a pre-existing situation for a short period of time, while he/she is particularly sensitive to the influence of the external environment, producing long-lasting effects on his/her future behaviour. Imprinting not only occurs within the animal kingdom, where it was first observed, but also within organizations, which, through imprinting, tend to shape their structure to reflect the environment in which they operate.

In so far as whether the path dependence theory explains how a company positions itself in a specific perspective, Marquis and Tilcsik's (2013) imprinting theory presents a deterministic view of the socio-economic environment, in which long-lasting existing structures are replicated in the future to determine our present reality, thus deterministically allowing us, with the knowledge of the past, to foresee future events. Although Marquis and Tilcsik (2013) maintain that imprinting is a deterministic theory because it suggests that the existing structure mechanistically replicates itself in the future, they overlook the fact that chance may play a role during the initial imprinting period in exposing the "focal entity" to one particular set of socio-economic conditions rather than another. Both chance and management choices play a role in creating multiple sensitive periods during the transformation phases of the organizational life, and management choices may play a role in imprinting decay, in which the initial imprinting fades to bring change and something new into the conditions, which are no longer determined or stable after the initial imprinting. The aforementioned diverse features of imprinting allow even Marquis and Tilcsik's (2013) imprinting theory to be related to the human agency perspectives presented earlier, as shown in Table 3, which demonstrates how both imprinting and organizational path theory refer to those four theoretical perspectives of determinism, hard incompatibilism, libertarianism and compatibilism.

Table 3 Features of imprinting and organizational path theory

\begin{tabular}{|c|c|c|}
\hline & Imprinting & Organizational path theory \\
\hline $\begin{array}{l}\text { Determinism } \\
\text { Everything is } \\
\text { determined and } \\
\text { there is no } \\
\text { strategic choice }\end{array}$ & $\begin{array}{l}\text { Imprinting - through which existing } \\
\text { structures replicate themselves in a pre- } \\
\text { set way - relates to the deterministic } \\
\text { perspective and explains why the external } \\
\text { environment is determined and why } \\
\text { organizations have little or no choice. }\end{array}$ & $\begin{array}{l}\text { In this environment, organizations can only } \\
\text { reach the lock-in phase as it would be } \\
\text { difficult to imagine the beginning of a path, } \\
\text { which according to Sydow et al. (2009) } \\
\text { originates from either a random event, } \\
\text { typical of the hard incompatibilist } \\
\text { perspective, or a free will event, typical of } \\
\text { the libertarian perspectives. }\end{array}$ \\
\hline $\begin{array}{c}\text { Hard } \\
\text { incompatibilism } \\
\text { There is little or } \\
\text { no strategic choice }\end{array}$ & $\begin{array}{l}\text { Imprinting, in which the initial conditions } \\
\text { are randomly presented to the focal entity, } \\
\text { relates to the hard incompatibilist } \\
\text { environment, in which the external } \\
\text { environment is undetermined and there is } \\
\text { little or no choice. }\end{array}$ & $\begin{array}{l}\text { In this environment, a random event } \\
\text { originates the organizational path, the lock- } \\
\text { in phase of which may take place in any of } \\
\text { the determinist or compatibilist perspectives } \\
\text { (see Figure 4). }\end{array}$ \\
\hline $\begin{array}{l}\text { Libertarianism } \\
\text { In this } \\
\text { undetermined } \\
\text { environment, } \\
\text { management has } \\
\text { choice at its } \\
\text { disposal }\end{array}$ & $\begin{array}{l}\text { Imprint decay, which occurs to create a } \\
\text { new condition which did not exist before, } \\
\text { can be traced in the libertarian } \\
\text { environment, where the external socio- } \\
\text { economic environment is undetermined } \\
\text { while management has choice at its } \\
\text { disposal. }\end{array}$ & $\begin{array}{l}\text { The path is initiated by the management's } \\
\text { choices and the lock-in phase may happen in } \\
\text { either the deterministic or the compatibilist } \\
\text { perspective (see Figure 4). Organizations } \\
\text { which operate in the libertarian perspective } \\
\text { cannot tolerate any inefficiency, never really } \\
\text { follow a set path as happens with the use of } \\
\text { strategic choice, continuously lock onto a } \\
\text { path and exit from it by breaking it, so as to } \\
\text { remain competitive in an undetermined and } \\
\text { continuously changing environment. }\end{array}$ \\
\hline $\begin{array}{l}\text { Compatibilism } \\
\text { This environment } \\
\text { is only partly } \\
\text { determined }\end{array}$ & $\begin{array}{l}\text { Imprinting in multiple sensitive periods, } \\
\text { which explains how the changing of } \\
\text { something determined occurs - can be } \\
\text { associated with the compatibilist } \\
\text { environment, according to which a } \\
\text { determined external socio-economic } \\
\text { environment can be changed by choice. }\end{array}$ & $\begin{array}{l}\text { The path that was originated in the hard } \\
\text { incompatibilist or libertarian environment } \\
\text { reaches the first lock-in phase, which is } \\
\text { followed by a series of breakings of the path } \\
\text { and successive new lock-ins, which take } \\
\text { place thanks to the strategic choice at the } \\
\text { management's disposal. }\end{array}$ \\
\hline
\end{tabular}

\footnotetext{
${ }^{2}$ Marquis and Tilcsik (2013) advance a three-part definition of imprinting that emphasizes (1) brief sensitive periods of transition during which the focal entity exhibits high susceptibility to external influences; (2) a process whereby the focal entity comes to reflect elements of its environment during a sensitive period; and (3) the persistence of imprints despite subsequent environmental changes.
} 
Table 3 allows us to relate imprinting, in each of the perspectives of the strategic choice determinism framework, to a phase of the organizational path theory, thus suggesting that the two theories could be part of a greater theory that explains how organizations originate and move from one perspective to another, although Marquis and Tilcsik (2013) present a more limited view of imprinting.

\section{The strategic choice determinism conceptual framework}

According to the human agency literature, which also encompasses strategic management, the ontological perspectives of determinism, hard incompatibilism, libertarianism and compatibilism possess the following main features:

\subsection{Determinism}

From a philosophical standpoint, a deterministic view of reality implies that knowledge of the past and of the laws that rule the natural world is sufficient to determine the future, as every event in nature happens because of the deterministic causation inherent in the laws of the physical world.

This implies that the human agent is not responsible for her actions due to the absence of the agent's choice. When limiting our analysis to strategic management, within the deterministic organizational structure, the roles and positions are hierarchically arranged so as to efficiently achieve the function of the system, and change takes place through the dividing and integrating of roles so as to adapt the organization's subsystems to changes in the environment, by means of technology, size and resource needs. Organizational behaviour is determined, constrained and adaptive, managers' roles are reactive, and change happens inside organizations in response to the external environment (Astley and Van de Ven 1983).

According to additional deterministic theories, companies mechanistically produce organizational performance, by possessing and exploiting assets, be they tangible or intangible such as Penrose's, (1959) Resource Based View of the firm (RBV) or by achieving a competitive advantage through the use of resources, to create entry barriers, such as Porter's (1981) five forces framework.

In the deterministic environment, managers obtain managerial effectiveness through the application of scientific laws or principles, be they laws of organization or laws of the marketplace Bourgeois (1984) or, as posited by Montanari (1979), organizational performance is achieved through the company's size, which is moderated by technology and managerial choices. According to structural determinism, companies create an internal structure to take advantage of market needs and dynamics and thereby produce performance, whose causation should be identified with the use of inferential statistics (Donaldson, 1987, 1997, 2005).

Further more Sydow et al. (2009), argues that the organizational path, which was originated by either a random event or an act of will, reaches the lock-in phase and Marquis and Tilcsik's (2013) imprinting theory explains how organizations produce performance mechanistically. In this context, Hrebiniak and Joyce (1985) maintain that, within the deterministic perspective the market competition ${ }^{3}$ intensity is very strong and organizations have minimal choice, therefore either adapt, by knowing and respecting the rules of the markets or are selected out.

In the deterministic perspective, organizational outcomes are obtained by knowing and exploiting the system or responding to the contingencies presented by the organizational context.

\subsection{Hard incompatibilism}

From a philosophical stance, the outcomes of the agent's decisions, which he/she makes in an undetermined external reality, are affected by chance or luck (Haji, 2000). The human agent is, therefore, not responsible for his/her actions.

Narrowing our interest to strategic management, in this environment, managers' responsibility is almost nonexistent, in determining the organizational outcomes, as things happen in the external environment by chance or luck. According to Astley and Van de Ven (1983), managers' behaviour is inactive and they have no power or control over the external environment.

The main planning theories are as follows: scenario planning, on the basis of which organizations deal with uncertainty by preparing to face a number of random external conditions the organizational context could present (Wack 1985); chaos theory, which foresees that difficult to forecast, small environmental changes occur constantly over time and may produce future unpredictable effects whose dynamics are difficult to control (Astley and Van de Ven, 1983); organizational failure, which, according to Mellahi and Wilkinson (2004), consists of the deterioration in an organization's adaptation to its microniche and the associated reduction of resources within

\footnotetext{
${ }^{3}$ When we refer to competition in each of the examined perspectives we consider the B2B, (B2) B2C or prosumers2B2prosumers competition.
} 
the organization; and finally, population ecology, which posits that the intractable macro-environmental conditions that operate in an industry determine the limits within which industry members can operate (Astley and Van de Ven 1983).

According to Sydow et al. (2009), the organizational path is started by a random event, which, as explained by Marquis and Tilcsik's (2013) imprinting theory, could be explained by the influence this random event has on the sensitive "focal entity". Finally, for Hrebiniak and Joyce (1985), in the hard incompatibilist perspective market competition intensity is inconsistent as chance can produce either low or high barriers to entry, which subjects organizations to adaptation by chance and natural selection.

In the hard incompatibilist perspective, organizational outcomes are uncertain and either greatly advantageous to organizations, in the case of found opportunity, or disastrous in the case that unknown/unmanaged risk produces undesired outcomes.

\subsection{Libertarianism}

From a philosophical standpoint, the concept of freewill implies that the agent's free decisions determine the world in which he/she lives (Kane, 1999). Narrowing our focus to strategic management, managers act according to the strategic choice at their disposal. They have power over the external environment and their responsibility is high as they create the laws that rule the external environment in determining organizational outcomes (Astley and Van de Ven, 1983) by (a) setting strategic goals, (b) choosing a specific field of activity, and selecting both (c) a technology and (d) an organizational structure (Child 1972).

Regarding these first two organizational activities, Varadarajan et al. (1992) propose two categories of strategic activity; the first is meant to stimulate something existing within the external environment and the second to create macro-environmental change favourable to the organization through the creation of something new, to the organization's advantage, thus establishing a link between strategic choice and innovation (Silverman, 1970; Varadarajan et al. 1992).

Also Schumpeter (1911)'s Mark I theory, according to which industries develop through the continuous creation of new ways to provide products and services, which, as Fontana et al. (2012) point out, takes place in an uncertain and turbulent environment even at the cost of destroying what exists, refers to the libertarian environment.

Sydow et al. (2009)'s organizational path theory maintains that, in the libertarian undetermined environment, the path is initiated by the choices of the organization's management, the lock-in phase of which may happen in either the deterministic or compatibilist perspective and the breaking of the path and the initiation of a new path can be explained by imprint decay, which occurs so as to create a new condition which did not exist before (Marquis and Tilcsik 2013).

In the libertarian perspective according to action theory, organizations, within the libertarian perspective, are continuously constructed, sustained and changed by managers through the use of strategic choice (Astley and Van de Ven, 1983), which managers use to reduce market competition intensity as market barriers to entry are constantly circumvented by the introduction of new products and services; therefore in consideration of the maximum amount of choice available to management in the libertarian perspective, adaptation happens by design (Hrebiniak and Joyce 1985). Voigt (2011) and Christensen and Raynor (2003) by defining new products and services, brought to market in the libertarian perspective, as "new-market disruptions" describe their revolutionary impact on the external environment.

In view of the above, in the libertarian perspective, organizational outcomes are obtained through the creation of something new, to the organization's advantage, through the use of strategic choice.

\subsection{Compatibilism}

From a philosophical perspective, the world is partly determined and the human agent can choose or change some aspects of it, becoming responsible for the choices he/she makes.

Whittington $(1988,2010)$, grounding his work on Giddens'(1984) structuration theory, which conforms to Bhaskar (1989)'s and Bourdieu's (1988) critical realism, posits that human social activity is characterized by a pre-existing structure which is essential to the existence of agency, which in turn is available to each individual who plays a role within a structure. Gidden's (1984) structuration theory, however, proposes that individuals, when acting as agents, not only participate and conform to social structures (i.e. family, work and policy) but also have the ability to change them. In this context, Leca and Naccache (2006) add that institutional actors not only comply with pre-existing laws and structures but also have the ability to act as agents who possess the power to alter, by procuring change from within, the deterministic, pre-set institutional structures in which they operate.

Focusing our interest on strategic management, managers' behaviour is interactive, collectively constructed and politically negotiated (Astley and Van de Ven, 1983). Managers have limited power and control over the 
external environment, which is ruled by laws that are independent of the organization, but they have the possibility to alter those laws.

Managers' responsibility, in determining organizational outcomes, is both limited by their choice of the deterministic theories that explain the external environment and open to change in the external environment.

Sarasvathy's (2001) effectuation, with which management determines new and sometimes unexpected objectives, starting from the available means, in contrast to deterministic causation, under which the means are determined so as to obtain the objectives, constitutes the mechanism according to which things happen in the compatibilist perspective. Schumpeter's (1942) Mark II theory, whose industries are characterized by stable environments with relatively high entry barriers, in which innovations are generated and developed by large established firms (Fontana et al. 2012), presents the features of the compatibilist environment, in which technological competition assumes the form of creative accumulation, with incumbent firms introducing innovations by means of a process of consolidation of their technological capabilities (Malerba 2005, p.382), thus growing and developing what exists.

In the compatibilist environment, companies which use product platforms or collections of modules or parts that are common to a number of products, intentionally developed to create customer value constantly modify them as described by Harland et al. (2020) to sustain organizational performance. According to Sydow et al.'s (2009) organizational path theory, in the compatibilist, partly determined environment, the path that was originated in the hard incompatibilist or libertarian environment reaches the first lock-in phase, which is followed by a series of breakings of the path and successive new lock-ins, which in turn can be explained through the occurrence of Marquis and Tilcsik's (2013) imprinting in multiple sensitive periods as necessary to obtain change in something determined.

Companies which are presented with both environmental determinism and differentiated choice, adapt with constraints, through the use of strategic choice, to the external environment (Hrebiniak and Joyce, 1985), in which market competition intensity is strong, and companies protect their businesses by both erecting barriers to entry and at the same time creating new products and services. In this context, Voigt (2011) and Christensen and Raynor (2003) by defining new ways to bring existing products and services to market, in the compatibilist perspective, as low-end disruptions describe their moderate impact on the external environment.

As such, in the compatibilist perspective, organizational outcomes are obtained through exploitation of the system and/or, through the use of strategic choice, the incremental growing, improving or constructing of what exists.

The theoretical considerations presented above allow us to create the strategic choice determinism framework, in which the two independent variables of strategic choice and determinism create a space composed of the four ontological perspectives of determinism, hard incompatibilism, libertarianism and compatibilism.

\begin{tabular}{|c|c|c|}
\hline & $\begin{array}{c}\text { Incompatibilism } \\
\text { (Determinism and strategic choice are } \\
\text { incompatible) }\end{array}$ & $\begin{array}{c}\text { Compatibilism } \\
\text { (Determinism and strategic choice can } \\
\text { coexist) }\end{array}$ \\
\hline $\begin{array}{l}\text { Environmental } \\
\text { determinism } \\
\text { is true }\end{array}$ & $\begin{array}{l}\text { Determinism } \\
\text { The environment imposes the organizational } \\
\text { strucuture. (Minimum choice, Adaptation or } \\
\text { selection out) } \\
\text { The organizational path reaches a lock-in phase } \\
\text { and then existing structures replicate through } \\
\text { imprinting. } \\
\text { "Outcomes are obtained by knowing } \\
\text { and exploiting the system." }\end{array}$ & $\begin{array}{l}\text { Organizational Choice is constrained by what } \\
\text { exists. (Differantiation or Focus differentiated } \\
\text { choice, Adaptation within constraints) } \\
\text { The organizational path goes through multiple } \\
\text { lock-in and breaking phases and imprinting } \\
\text { occurs through multiple sensistive periods. } \\
\text { "Outcomes are obtained by exploiting } \\
\text { the system or with the use of strategic } \\
\text { choice by incrementally growing, } \\
\text { improving or constructing on what } \\
\text { exists." }\end{array}$ \\
\hline $\begin{array}{l}\text { Environmental } \\
\text { determinism }\end{array}$ & $\begin{array}{l}\text { Hard incompatibilism } \\
\text { Organizations are subject to environmental } \\
\text { selection. (undifferentiated and Incremental } \\
\text { choice, adaptation by chance or Natural Selection). } \\
\text { A random event starts the organizational path or } \\
\text { affects and imprint sensitive subject. } \\
\text { "Outcomes are uncertain as they can be } \\
\text { greatly advantageous to organizations, } \\
\text { in case of found opportunity, but } \\
\text { disastrous in case unknown risk } \\
\text { produces undesired outcomes." }\end{array}$ & $\begin{array}{l}\text { Libertarianism } \\
\text { Organizations are driven by Individual choice. } \\
\text { (Strategic Choice, Maximum choice, Adaptation } \\
\text { by design) } \\
\text { Organizations continuously lock in and out of the } \\
\text { path. Imprinting takes place and decays. } \\
\text { "Outcomes are obtained by creating } \\
\text { something new to the organization's } \\
\text { advantage, with the use of strategic } \\
\text { choice." }\end{array}$ \\
\hline
\end{tabular}

Fig. 5 The strategic choice determinism framework 
An ontological perspective of the strategic choice/determinism framework shown in Figure 5 refers to each of the quadrants generated by the variables of strategic choice and determinism. Each perspective refers to a particular organizational context, which encompasses both organizations' internal and external environments possessing the features of a particular ontological perspective. Therefore, in the continuation of this paper, the terms environment or industry, and organizational structure, refer respectively to the ontological perspectives' external and internal environments, be they deterministic, hard incompatibilist, libertarian or compatibilist. Each perspective allows us to look at and appreciate specific empirical situations or environments.

A perspective of the strategic choice determinism framework can be described as what you would see if you wore glasses with lenses of a particular colour. In the physical world, the separation of the primary colours, red, green and blue, allows us to obtain an image constituted of colour components. Similarly, each perspective of the strategic choice determinism framework identifies one component of the whole socio-economic reality, just as the combination of red, green and blue allows one to analyse and recreate all the colours and shades of an image.

Theories which apply to a particular perspective (some apply to one or more than one environment) are valid for a particular combination of strategic choice and determinism, typical of the environment or managerial situation they refer to.

\section{Empirical evidence of the framework's real-life existence}

To empirically test the real-life existence of the ontological perspectives that compose the strategic choice determinism framework, it is imperative that an appropriate framework of analysis is developed.

In this direction, we consider (a) creation through theoretical sampling, used for the analysis of each studied ontological perspective, of a sample of companies, which will be quantitatively studied by (b) investigating the existence of correlations and (c) conducting a longitudinal regression between financial-statement-derived variables indicative of companies' performance and variables being chosen to represent a strategic choice or deterministic approach to strategy.

\subsection{Theoretical sampling and data sample creation}

By identifying the features that each ontological perspective of the theoretical framework presented above possesses in the real world, it is possible to identify real-life industries possessing those features. The sample of companies from these industries, representative of a particular ontological perspective, can then be quantitatively analysed to look for any relationship between management's reliance on strategic choice or determinism, and organizational outcomes.

To identify the real-life features of each ontological perspective, we should think of the whole socio-economic world as something that can initially be divided into two perspectives: a deterministic environment (top-left box of the framework), in which companies do not rely heavily on strategic choice and are expected to operate in a deterministic or contingent way, and a hard incompatibilist environment (bottom-left box of the framework), in which companies operate in an uncertain or undetermined socio-economic environment without relying on strategic choice.

From each of these two perspectives, it is possible to derive two additional perspectives by considering those companies which use strategic choice to produce organizational performance.

Thus, starting from the previously described determined and undetermined real-life environments, by identifying the strategic choice component available to managers within each of the two environments (Astley and Van de Ven 1983; Emirbayer and Mische, 1998; Hrebiniak and Joyce 1984; Kane 1999), the compatibilist and libertarian ontological perspectives can be identified.

The industries which utilize a component of strategic choice in the way they plan and operate in a stable or determined socio-economic environment will be considered to operate in a compatibilist way (top-right box of the framework), while the industries which operate in an uncertain environment, which utilize strategic choice as a main feature of planning, will be considered to operate according to the libertarian ontological perspective (bottom-right corner of the framework).

Figure 6 presents the real-life features of each perspective and suggests some real-life business environments possessing these features. 


\begin{tabular}{|c|c|}
\hline $\begin{array}{l}\text { Determinism } \\
\text { - The external environment is governed by } \\
\text { fixed rules } \\
\text { - Outcomes of actions carried out in the } \\
\text { environment can be forecasted } \\
\text { - Organizations' decisions are dictated by } \\
\text { conditions in the external environment } \\
\text { Activities with deterministic features } \\
\text { - Government bonds and large } \\
\text { organizations' bond market } \\
\text { - Pension systems and pension funds } \\
\text { - Insurances Banking }\end{array}$ & $\begin{array}{l}\text { Compatibilism } \\
\text { - The external environment is governed by } \\
\text { fixed rules which however can be changed } \\
\text { - Outcomes of actions carried out in the } \\
\text { environment can be forecasted } \\
\text { - Organizations' decisions are dictated by } \\
\text { both the conditions in the external } \\
\text { environment and managerial choices } \\
\text { Activities with Compatibilist features } \\
\text { - The exploitation of networks } \\
\text { - Grids or infrastructure in general } \\
\text { - Goods distribution }\end{array}$ \\
\hline $\begin{array}{l}\text { Hard incompatibilism } \\
\text { - The external environment is undetermined } \\
\text { - There are no rules which allow the } \\
\text { prediction of environmental future behavior } \\
\text { - Businesses and markets are affected by } \\
\text { technological, cultural and social change } \\
\text { - Organizations' management lacks of } \\
\text { adequate competencies } \\
\text { - Lack of knowledge or wrong interpretation } \\
\text { of information produces mismatch between } \\
\text { managerial choices and expected } \\
\text { performances } \\
\text { Hard incompatibilist activities } \\
\text { - Startups - Companies in financial difficulties } \\
\text { - Companies facing environmental change }\end{array}$ & $\begin{array}{l}\text { Libertarianism } \\
\text { - The external environment is undetermined } \\
\text { - There are no rules which allow to predict } \\
\text { the environmental future behavior } \\
\text { - Businesses and markets are affected by } \\
\text { technological, cultural and social change } \\
\text { - The environment future behavior and rules } \\
\text { are dictated by management choices } \\
\text { - Management choices allow to take } \\
\text { advantage of the environment uncertainty } \\
\text { Activities with libertarian features } \\
\text { - Technology companies } \\
\text { - Software companies } \\
\text { - Telecommunication companies } \\
\text { - Web information management }\end{array}$ \\
\hline
\end{tabular}

Fig. 6 Features of real-life socio-economic ontological perspectives, and the companies and industries that operate in them

\subsubsection{Companies representative of the deterministic environment}

Looking at the deterministic environment it is possible to see that Figure 6 identifies the following real-life industries: insurance, banking and pension fund. For the purpose of our study it is worth noting that Zajac et al (2000) analyse, over a nine-year period, a sample of over 4,000 companies operating in the savings and loan industry, which, according to our theoretical sampling method, is a deterministic industry, and provide evidence that companies operating in a deterministic perspective, such as those in the savings and loan industry (S\&L), produce positive organizational performance only by acting deterministically. Zajac et al.'s (2000) work, therefore, produces empirical evidence of the real-life existence of the deterministic ontological perspective.

\subsubsection{Companies representative of the hard incompatibilist environment}

Although it is difficult to exactly point out hard incompatibilist industries, as any company can enter this environment due to either epistemic endogenous factors (management's lack of competencies and/or knowledge (Tversky, and Kahneman 1974)) or exogenous factors such as an industry undergoing sudden change, we are going to provide some examples that indicate the real life existence of this ontological perspective. For instance the creation of Pfizer's Viagra, which only by pure chance became the famous and extremely lucrative drug it did for Pfizer, emerging when the company was looking for a cure for angina (De Rond and Thietart 2007) or conventional photography market being adversely affected, in the years 2000 , by the introduction of digital cameras and the Internet.

In addition, Fitza (2013), in a study of 25,859 companies sampled from several business environments, found that CEOs' choices produce random results in terms of companies' performance Fitza (2017). One explanation of this finding could be the existence of different ontological perspectives, one being hard incompatibilism.

Although these empirical indications from the literature suggest the real-life existence of the hard incompatibilist ontological perspective, it would be difficult to apply the research methodology presented later in this paper, which correlates and regresses companies' ratios, indicative of the use of strategic choice and determinism, with respect to performance in an environment in which performance is mainly produced by chance or luck. For this reason, at this stage, the real-life existence of the hard incompatibilist perspective, although not conclusively so, is only demonstrated by the above qualitative empirical examples. 


\subsubsection{Companies representative of the libertarian and compatibilist environments}

To look for empirical evidence of the existence of the libertarian and compatibilist environments, we collected data samples, to be analysed, from the NASDAQ stock exchange's website, over a four-year period, using the theorical sampling theory presented above in section 4.1. Within a selected industry, companies were chosen that met a certain size criterion, which is coherent with the theoretical background, according to which companies' activities should be of such a size to produce effects capable of influencing and shaping the external environment, which cannot always be said to be the case with smaller companies.

Although, in performance measurement research, organizational size tends to be calculated as the logarithm of a firm's assets (e.g. Ittner et al. 2003) or the logarithm of its revenues (e.g. Bushman et al. 1996; Gupta, 1987), and in the compensation literature it is common to find organizational size measured as a composite of organizational total assets, turnover and number of employees (e.g. Gomez-Mejia et al. 1987; Werner and Tosi, 1995; Werner et al. 2005), for the NASDAQ's publicly listed companies, market capitalization is a common criterion used for determining their size, such as in Forbes and other finance magazines.

For the above reasons, in order to select an industry-representative sample, we chose a market capitalization threshold level of 10 billion USD, which corresponds to the NASDAQ's threshold for defining Mega cap and Large cap companies, thus discarding Mid, Small, Micro and Nano cap companies.

In the libertarian environment, according to the theoretical background, organizations should deal with uncertainty in the external environment by creating something new to their advantage, thus reducing uncertainty. This organizational behaviour can be expected in organizations which operate in the Technology industry, and its creation, promotion and distribution as shown in table 4.

In the compatibilist ontological perspective, we look at a deterministic socio-economic environment in which the addition of strategic choice to management's options creates the possibility of influencing and altering the external environment. According to this principle, the NASDAQ's Public utilities and Consumer non-durable goods industries, which are described in Table 4, possess compatibilist features as, on the one hand, they provide a uniform and constant supply of goods and services, and on the other hand the processes used to obtain these goals can be altered and improved with the use of management strategic choice in promoting innovation.

These samples of companies can be considered representative of all the industries in which they are active, to the extent the NASDAQ is considered to be representative of the whole market.

Table 4 Summary of NASDAQ libertarian and compatibilist industries and 10 billion USD sample

\begin{tabular}{|c|c|c|c|c|c|}
\hline Industry & Features of the industry & $\begin{array}{l}\text { Number } \\
\text { of } \\
\text { companies }\end{array}$ & $\begin{array}{c}\text { Total } \\
\text { capitalization } \\
\text { in bill. USD }\end{array}$ & $\begin{array}{c}\text { Sample } \\
\text { size }\end{array}$ & $\begin{array}{c}\text { Sample } \\
\text { capitalization } \\
\text { in bill. USD }\end{array}$ \\
\hline \multicolumn{6}{|c|}{ Libertarianism } \\
\hline $\begin{array}{l}\text { Technology } \\
\text { industry } \\
(28 / 02 / 15)\end{array}$ & $\begin{array}{c}\text { Computers and software, } \\
\text { semiconductors, EDP services, } \\
\text { data programming and data } \\
\text { processing. }\end{array}$ & 682 & 5,192 & 57 & $\begin{array}{c}3,613 \\
70 \% \text { of total } \\
\text { capitalization }\end{array}$ \\
\hline \multicolumn{6}{|c|}{ Compatibilism } \\
\hline $\begin{array}{c}\text { Consumer } \\
\text { non-durable } \\
\text { industry } \\
(07 / 03 / 15)\end{array}$ & $\begin{array}{l}\text { Farming, seeds, milling, } \\
\text { beverages, food distribution, } \\
\text { packaged food, electronic } \\
\text { components, apparel, footwear } \\
\text { manufacturing, toys, } \\
\text { telecommunication equipment, } \\
\text { food chains, motor vehicles, meat, } \\
\text { poultry and fish, speciality foods. }\end{array}$ & 235 & 4,069 & 47 & $\begin{array}{c}3,319 \\
81 \% \text { of total } \\
\text { capitalization }\end{array}$ \\
\hline $\begin{array}{c}\text { Public } \\
\text { utilities } \\
\text { industry } \\
(\mathbf{2 8} / \mathbf{0 2} / \mathbf{1 5})\end{array}$ & $\begin{array}{l}\text { Natural gas, electricity distribution } \\
\text { and generation, water distribution, } \\
\text { electricity utilities. }\end{array}$ & 292 & 3,258 & 60 & $\begin{array}{c}2,377 \\
73 \% \text { of total } \\
\text { capitalization }\end{array}$ \\
\hline
\end{tabular}




\section{Empirical investigation of the libertarian and compatibilist perspectives}

In consideration of the fact that Zajac et al.'s, (2000) paper provides empirical evidence of the existence of the deterministic perspective and that it is not possible to quantitively analyse the hard incompatibilist environment we present the research hypothesis which will allow us to study the libertarian and the compatibilist environments.

\subsection{Research hypotheses}

When looking at how organizations are expected to behave in the compatibilist and libertarian ontological perspectives, it can be seen that both the literature and previous research suggest that:

a) in the libertarian ontological perspective, organizations exploit their assets by creating something new, through innovation and its promotion, which is essential and constitutes the main driver of organizational performance (Kane 1999; Astley and Van de Ven 1983);

b) in the compatibilist ontological perspective, organizations produce organizational performances through exploiting their assets by both adhering to the norm and using strategic choice to innovate and promote innovation (Bourgeois 1984; Astley and Van de Ven 1983).

\begin{tabular}{|c|c|c|}
\hline & \multicolumn{2}{|c|}{ Strategic choice } \\
\hline 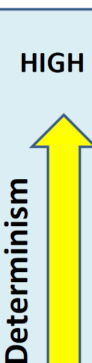 & $\begin{array}{l}\text { Determinism } \\
\text { The effect of strategic choice on } \\
\text { performances is: } \\
\text { INDIFFERENT OR DETRIMENTAL } \\
\text { (Total assets and observation of the } \\
\text { rules which determine the environment } \\
\text { are sufficient to produce performances; } \\
\text { strategic choice used by management } \\
\text { could either be indifferent or } \\
\text { detrimental) Zajac et al. (2000) }\end{array}$ & $\begin{array}{l}\text { Compatibilism } \\
\text { The effect of strategic choice on } \\
\text { performances is: } \\
\text { IMPROVING (with moderate } \\
\text { correlation) } \\
\text { (Total assets and the use of the rules, } \\
\text { which determine the environment, } \\
\text { produce a basic level of performance } \\
\text { that can be improved with the use of } \\
\text { strategic choice) }\end{array}$ \\
\hline 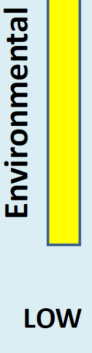 & $\begin{array}{l}\text { Hard incompatibilism } \\
\text { The effect of strategic choice on } \\
\text { performances is: } \\
\text { RELATED TO CHANCE } \\
\text { (There are no rules and little choice, } \\
\text { which produces random effects on } \\
\text { performances) }\end{array}$ & $\begin{array}{l}\text { Libertarianism } \\
\text { The effect of strategic choice on } \\
\text { performances is: } \\
\text { INDISPENSABLE (with high } \\
\text { correlation) } \\
\text { (In an undetermined environment, only } \\
\text { the rules which are created with the } \\
\text { use of strategic choice allow the use of } \\
\text { companies' total assets to produce } \\
\text { performances) }\end{array}$ \\
\hline
\end{tabular}

Fig. 7 Framework showing the effects of strategic choice on performance

On the strength of these considerations and the strategic choice determinism framework, it is possible to highlight some of the latter's features, as shown in Figure 7. This figure suggests the relationship between either strategic choice or determinism and organizational performance that we expect to identify through this empirical study, and enables us to generate the research hypotheses regarding the role strategic choice plays in producing sales and organizational performance, in both the libertarian and compatibilist ontological perspectives.

\subsection{Strategic choice and revenues in the libertarian real-life perspective}

As previously shown, the libertarian ontological perspective is uncertain by definition, until the agent shapes it to its advantage (Kane 1999). Environmental uncertainty therefore requires the use of strategic choice to continuously manage and harness the uncertain effects of the environment.

These considerations indicate that, in the libertarian ontological perspective, in order to produce sales, organizations need to rely on the constant use of strategic-choice-based activities, consisting, for the purpose of this research, of at least innovation and its promotion, as was extensively shown in the theoretical background section.

All of these activities rely on an underlying organizational structure represented by total assets, which could need to be modified as a result of the innovation process.

In view of the preceding analysis, the following research hypothesis is proposed: 
Hypothesis 1 In a libertarian ontological perspective, revenues are mainly dependent on the level of strategicchoice-based activities (innovation and its promotion) carried out by the organization, and on total assets.

\subsection{Strategic choice and revenues in the compatibilist real-life ontological perspective}

In the compatibilist external environment, unlike in the libertarian ontological perspective, strategic choice and determinism coexist (Bourgeois, 1984), producing an environment that is partly determined and can produce some levels of organizational performance without the need for companies' management to use any strategic choice. Therefore, in this environment, management uses strategic choice to increase or enhance performance that would otherwise still exist. The resulting research hypothesis is as follows:

Hypothesis 2 In a compatibilist ontological perspective, revenues are equally dependent on the level of strategic-choice-based activities (innovation and its promotion) carried out by the organization and on total assets.

Strategic-choice-based activities play a less important role in explaining the revenues of companies operating in a compatibilist ontological perspective.

Therefore, Hypothesis 2 is confirmed by a lower dependence of revenues on strategic-choice-based activities and a stronger dependence of revenues on total assets than in the libertarian ontological perspective.

\subsection{Strategic choice and organizational performance in the libertarian perspective}

The dependence between strategic choice and revenues would also suggest that organizations' performance indicators, such as EBITDA and ROA, which depend on revenues, should be related to the amount of strategic choice used by management. This should be the case within libertarian companies, to the extent that, if strategic choice were not used, these companies would either produce no performance or would produce it in a chancerelated way, thus moving organizations to the hard incompatibilist ontological perspective. In view of these considerations, we propose the following research hypothesis:

Hypothesis 3 The organizational performance of companies operating in a libertarian ontological perspective is more dependent on strategic-choice-based activities than total assets.

Hypothesis 3 is confirmed by both a strong correlation between strategic-choice-based activities and organizational performance, and a regression that allows the prediction of performance as a function of the extent to which strategic choice is used.

\subsection{Strategic choice and organizational performance in the compatibilist perspective}

From the preceding analysis, it follows that total assets, which are the main deterministic component within a firm operating in the compatibilist ontological perspective, guarantee some level of performance regardless of the level of strategic choice used by management. However, if organizations used strategic choice, they could improve sales and therefore possibly overall performance. This leads to the following research hypothesis:

Hypothesis 4 The organizational performance of companies operating in a compatibilist ontological perspective is equally dependent on strategic-choice-based activities and on total assets.

A correlation and a similar level of regression between the organizational performance variables and the variables of both strategic choice and determinism is expected.

\subsection{Strategic choice in the libertarian and compatibilist perspectives}

So far, it has been argued that organizations use strategic choice similarly in both the libertarian and compatibilist ontological perspectives; however, they produce different contextual outcomes according to the level of determinism that characterizes each ontological perspective. This assumption could be confirmed and validated, thus strengthening the strategic choice determinism framework, through empirical evidence showing that the use of strategic choice more strongly drives organizational performance in the libertarian than in the compatibilist ontological perspective. These considerations suggest the following research hypotheses:

Hypothesis $\mathbf{5}$ There is a stronger dependence between strategic-choice-based activities and revenues in a libertarian than in a compatibilist ontological perspective. 
Hypothesis 6 There is a weaker dependence between total assets and revenues in a libertarian than in a compatibilist ontological perspective.

Hypothesis 7 There is a stronger dependence between strategic-choice-based activities and performance in a libertarian than in a compatibilist ontological perspective.

Hypothesis $\mathbf{8}$ There is a weaker dependence between total assets and organizational performance in a libertarian than in a compatibilist ontological perspective.

\subsection{The Variables}

\subsubsection{Independent variables}

Organizations actively influence and shape their environment with the use of tactics and strategies, which involve the use of marketing, target pricing, negotiation, coaptation, mergers, cooperation and lobbying (Schreyögg 1980). Similarly, Varadarajan et al. (1992) present non-deterministic, strategic-choice-based strategies, which rely on the creation of something new or the change of something existing within the socio-economic environment in which a company operates.

Table 6 shows the strategic-choice-related activities suggested Schreyögg (1980) and Varadarajan et al. (1992) and links them to standard financial statement P\&L cost entries. Similarly, Finkelstein and Hambrick (1990) and Haynes and Hillman (2010) used the same financial statement cost entries, as a quantitative indication of management's use of strategic choice, in their study of how board capital affects strategic change.

To summarize, the literature shows that organizational management utilizes strategic-choice-based strategies to innovate, by spending on research and development (R\&D), by promoting its results by spending on sales and marketing $(\mathrm{S} \& \mathrm{M})$, or by spending on public relations and lobbying costs, which are accounted for in selling, general and administrative (SG\&A) financial statement cost entries.

Together with variables which are indicative of strategic choice, there are variables which can deterministically influence organizational performance by constraining and also informing choice. Although De Rond and Thietart (2007) identify several variables as comprising the causal background, which includes management's knowhow, competence, age, the organizational structure and the general state of the economy, in this study only total assets are used as an indication of how much a company relies on the deterministic aspects of its structure. Total assets is a significant value, reflecting both the capital employed (e.g. loans, shareholders' capital, profit from previous years, etc.) and all the resources (tangible and intangible) an organization utilizes (e.g. equipment, properties, patents etc.) to pursue its strategic objectives.

\subsubsection{Dependent variables}

The impact of the use of strategic choice and determinism on organizations could be measured by identifying and measuring organizational performance indicator variations in search of a possible correlation with the variation in strategic choice and determinism. According to Gomez-Mejia et al. (1988) and Weiner and Mahoney (1981), organizational performance cannot be captured by a single measure but only by a host of different organizational performance indicators. As such, we use three different indicators, i.e. revenue, earnings before interest, tax, depreciation and amortization (EBITDA) and return on assets (ROA) (see Table 5 for variable definitions and Appendix A for descriptive statistics). 
Table 5 Definitions of variables

\begin{tabular}{|c|c|c|c|}
\hline Variable & $\begin{array}{c}\text { Variable description } \\
\text { (Values shown in the P\&L of companies' financial } \\
\text { statements in millions of USD) }\end{array}$ & $\begin{array}{l}\text { Reason for use of } \\
\text { variable }\end{array}$ & $\begin{array}{l}\text { Nature of } \\
\text { variable }\end{array}$ \\
\hline $\mathrm{R} \& \mathrm{D}$ & $\begin{array}{l}\text { Describes innovation intensity: } \\
\text { research and development cost for the year } \mathrm{t}\end{array}$ & $\begin{array}{l}\text { Strategic choice } \\
\text { component }\end{array}$ & Independent \\
\hline S\&M & $\begin{array}{l}\text { Describes marketing and advertising intensity: } \\
\text { sales and marketing cost for the year } \mathrm{t}\end{array}$ & $\begin{array}{c}\text { Strategic choice } \\
\text { component }\end{array}$ & Independent \\
\hline SG\&A & $\begin{array}{l}\text { Related to public relations, political influence and } \\
\text { lobbying costs: } \\
\text { sales, general and administrative cost for the year } \mathrm{t}\end{array}$ & $\begin{array}{l}\text { Strategic choice } \\
\text { component }\end{array}$ & Independent \\
\hline $\begin{array}{l}\text { Total } \\
\text { Assets. }\end{array}$ & $\begin{array}{l}\text { Encompasses all the resources an organization utilizes to } \\
\text { pursue its strategic objectives: } \\
\text { Total Assets }(\mathrm{t})=\text { Total Assets for the year } \mathrm{t}\end{array}$ & $\begin{array}{c}\text { Deterministic } \\
\text { component }\end{array}$ & Independent \\
\hline REVENUE & $\begin{array}{l}\text { Sales for the year } \mathrm{t} \text { : } \\
\operatorname{SALESc(t)}=\text { yearly turnover for the year } \mathrm{t}\end{array}$ & $\begin{array}{l}\text { Possible correlation } \\
\text { with independent } \\
\text { variables }\end{array}$ & Dependent \\
\hline ROA & $\begin{array}{l}\text { Provides an indication of how much net income, shown } \\
\text { as a percentage, organizational assets can produce: } \\
\qquad \operatorname{ROA}_{(\mathrm{t})}=\frac{\text { net income }(t)}{\text { total assets }(t)}\end{array}$ & $\begin{array}{l}\text { Possible correlation } \\
\text { with independent } \\
\text { variables }\end{array}$ & Dependent \\
\hline EBITDA & $\begin{array}{l}\text { EBITDA allows the evaluation of an organization's } \\
\text { ability to produce margins on revenues. EBITDA for the } \\
\text { year t: } \\
\operatorname{EBITDAc}_{(\mathrm{t})}=\mathrm{EBIT}_{(\mathrm{t})}+\text { depreciation and amortization }(\mathrm{t})^{-}\end{array}$ & $\begin{array}{l}\text { Possible correlation } \\
\text { with independent } \\
\text { variables }\end{array}$ & Dependent \\
\hline
\end{tabular}

The vector of our independent variables comprises indicators of costs related to strategic choice and determinism, such as R\&D, S\&M, SG\&A and Total Assets. These variables are shown in the P\&L of the companies' financial statements in millions and indicate, in numerical form, the level of strategic-choice-based activities used by management during a particular year. Total Assets, which provides an indication of how much each company relies on deterministic planning, is a significant variable as it reflects both the capital employed (e.g. loans, shareholders' capital, profit from previous years etc.), and all the resources (tangible and intangible) an organization utilizes (e.g. equipment, properties, patents etc.) to pursue its strategic objectives.

\subsubsection{Control variables}

According to Spector and Brannick (2013), control variables should be drawn from the theoretical background and collected together with the research data. The most meaningful and available control variable, with regard to our theoretical background, is organizational size, which in consideration of the kind of companies analysed in the samples, is measured by the companies' capitalization, which is also used to select the companies for our samples.

\subsubsection{Initial qualitative evidence of the existence of the compatibilist and libertarian perspectives}

In the two compatibilist industry samples, only 14 companies out of 107 post $R \& D$ costs in their balance sheets. This shows that, as opposed to the libertarian ontological perspective, where all companies report R\&D costs in their financial statements, in the compatibilist ontological perspective, only $12 \%$ of companies do it. This consideration alone, in a qualitative way, indicates that strategic-choice-based activities such as innovation and $\mathrm{R} \& \mathrm{D}$, in a compatibilist ontological perspective, are not the main drivers of organizational performance.

\subsection{Methodology}

For the empirical investigation, a standard panel data analysis is utilized. Among the many different existing estimators, we opt for Feasible Generalized Least Square (FGLS) as it provides consistent estimates and is capable of dealing with heteroskedastic and possibly serially correlated observations (Croissant and Millo 2008; Wooldridge, 2002). As Croissant and Millo (2008) point out, general FGLS estimators are based on a two-step estimation process. First, an ordinary least square (OLS) model is estimated and produces $\hat{u}_{\text {it }}$ residuals. The $\hat{u}_{\text {it }}$ residuals are used to estimate an error covariance matrix, which is used to regress the variables' variations from 
their mean over time, within each company if effects=individuals is chosen, or across companies if effects=time is chosen. The resulting estimated error covariance matrix equals $\widehat{V}=I_{n} \otimes \widehat{\Omega}$ where

$$
\widehat{\Omega}=\sum_{i=1}^{n} \frac{\hat{u}_{i t} \hat{u}_{i t}^{T}}{n}
$$

$n$ is the number of cases and $u$ are the residuals. We use the Hausman test to choose whether the FGLS effects = individual model or the FGLS effects = time model better describes the relationship between the dependent and independent variables and can be used to accept or reject the research hypotheses. As Croissant and Millo (2008) explain, the Hausman test indicates whether the two models are significantly different or not. If the two models were not significantly different, the model that explained the most variance would be chosen by looking at both the $\mathrm{R}^{2}$ and the mean of the error residual matrix and choosing the model that made them as close to zero as possible. If the two models were significantly different, the FGLS effects = individual would be chosen, as this model would guarantee maximum consistency (Wooldridge 2002).

\subsubsection{Models used to test the libertarian and compatibilist perspectives}

The regression between the dependent and independent variables is carried out utilizing the six linear models shown in Table 6, derived from the method presented above.

Table 6 Regression research models

\begin{tabular}{|c|l|}
\hline & Compatibilist ontological perspective \\
\hline Model 1 & Tests the dependence of revenues on R\&D, SG\&A and Total Assets \\
\hline Model 2 & Tests the dependence of EBITDA on R\&D, SG\&A and Total Assets \\
\hline Model 3 & Tests the dependence of ROA on R\&D, SG\&A and Total Assets \\
\hline & Libertarian ontological perspective \\
\hline Model 4 & Tests the dependence of revenues on R\&D, SG\&A and Total Assets \\
\hline Model 5 & Tests the dependence of EBITDA on R\&D, SG\&A and Total Assets \\
\hline Model 6 & Tests the dependence of ROA on R\&D, SG\&A and Total Assets \\
\hline
\end{tabular}

\section{Results, evaluation and discussion}

The variables' descriptive statistics indicate that the data are strongly heteroskedastic and the Pearson correlations show strong correlation between some of the variables. Table 7 presents the model results used to explore the libertarian and compatibilist ontological perspectives. In carrying out the analysis, FGLS models were used to test both the within individual effects and the between time effects variations, which produced similar results.

Table 7 Regression results for the libertarian and compatibilist ontological perspective

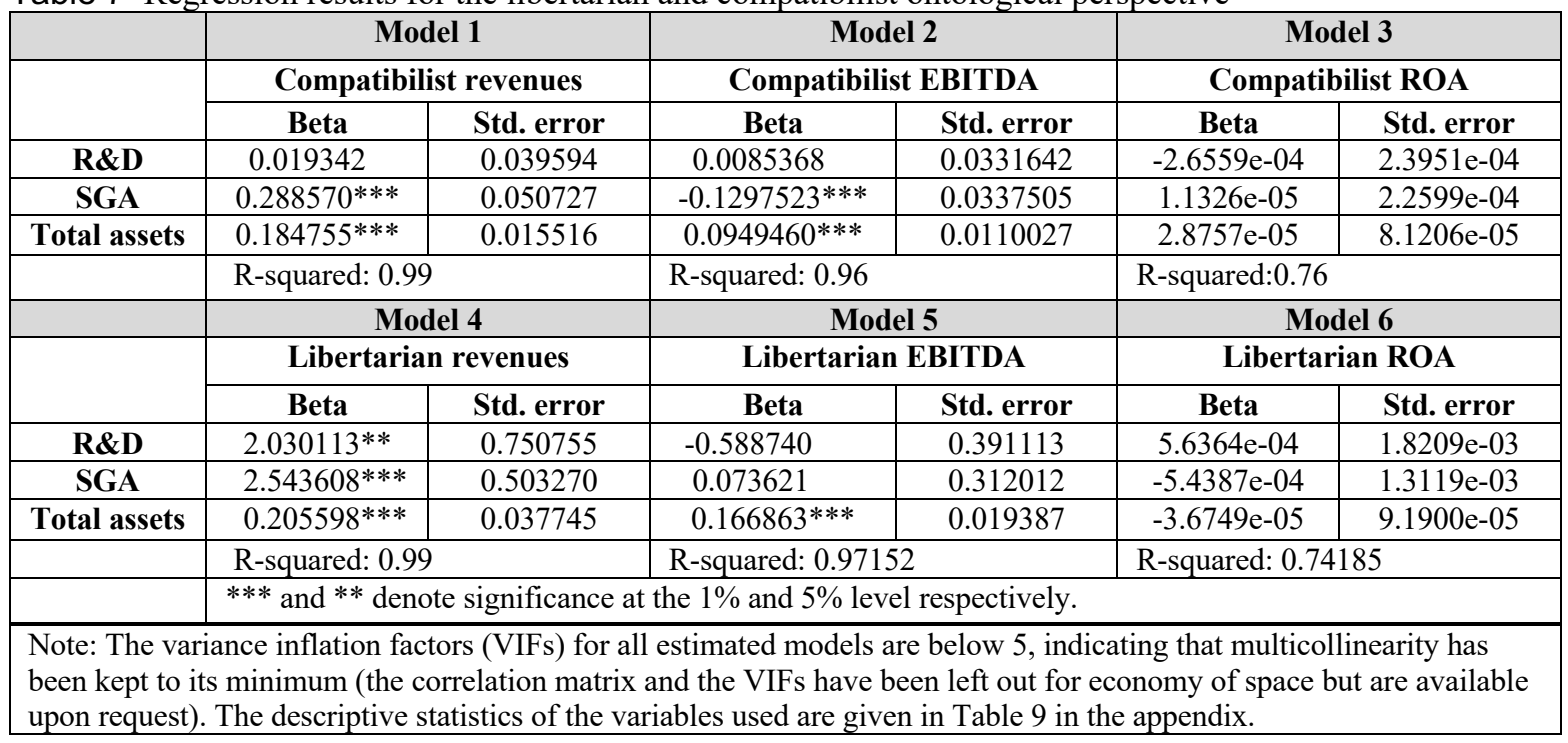


The analysis is therefore based on the within variation model as it is known to produce more consistent results. Notwithstanding the FGLS regression consistency, even in the presence of high heteroskedasticity in the sample data or a non-constant variance across the dependent and independent variables, to further test the model robustness, the following methods were also applied to normalize the data:

1) reduction to a percentage of the maximum observed value for each variable;

2) $\log$ reduction of data to produce a normally distributed variable data histogram;

3) distribution improvement by replacing outliers more than three standard deviations away from the mean, with values contained within three standard deviations from the mean in each direction.

The six models, after each of the above normalization processes, produced similar results, guaranteeing high consistency of research results notwithstanding the high heteroskedasticity of the collected data.

Table 8 Summary of interpretation of results with respect to research hypotheses

Hypotheses
Hypothesis 1 In a libertarian
ontological perspective, revenues are
mainly dependent on the level of
strategic-choice-based activities
(innovation and its promotion) carried
out by the organization, and on total
assets.
assets.

\section{Regression results interpretation}

Model 4 shows that, in the libertarian ontological perspective (Hypothesis 1), R\&D and SG\&A positively contribute to yearly revenues, with beta coefficients of respectively 2 and 2.5 .

This means that, for every billion USD spent on R\&D and SG\&A, revenues will increase by respectively 2 and 2.5 billion. In the same model, the role of Total Assets is marginal, since it increases with a beta coefficient of 0.2 , contributing less than a tenth to the increase in revenues compared to strategic-choice-based activities.

These facts suggest that, in the libertarian ontological perspective, revenues are driven and produced by strategic-choice-based activities, which activate Total Assets, which by themselves could not produce revenues.

Hypothesis 2 In a compatibilist ontological perspective, revenues are equally dependent on the level of strategic-choice-based activities (innovation and its promotion) carried out by the organization and on total assets.

Hypothesis $\mathbf{3}$ The organizational performance of companies operating in a libertarian ontological perspective is more dependent on strategic-choicebased activities than total assets.

Hypothesis $\mathbf{4}$ The organizational performance of companies operating in a compatibilist ontological perspective is equally dependent on strategicchoice-based activities and on total assets.

Hypothesis $\mathbf{5}$ There is a stronger dependence between strategic-choicebased activities and revenues in a libertarian than in a compatibilist ontological perspective.

Hypothesis 6 There is a weaker dependence between total assets and revenues in a libertarian than in a compatibilist ontological perspective.

Hypothesis 7 There is a stronger dependence between strategic-choicebased activities and performance in a libertarian than in a compatibilist ontological perspective. (Hypothesis 2), the dependence on strategic choice is limited to SG\&A, since R\&D does not explain revenues. Total Assets contribute similarly to SG\&A in explaining revenues, with similarly small beta coefficients of respectively 0.18 and 0.28 , thus supporting research Hypothesis $\mathrm{H} 2$.

Model 5 shows that Total Assets explain EBITDA for the libertarian ontological perspective whilst model 6 did not produce significant results.

Model 2 suggests that Total Assets explain EBITDA for the libertarian ontological perspective whilst model 3 failed to produce significant results.

The comparison of Models 1 and 4 shows that revenues are mainly produced, in a libertarian ontological perspective, by strategicchoice-based activities, while in the compatibilist ontological perspective they are equally produced by SG\&A and Total Assets.

The role of strategic-choice-based activities is greatly reduced in the compatibilist ontological perspective for two reasons: only SG\&A contributes to produce sales, and its contribution comes with a beta coefficient of 0.18 as opposed to 2.5 in the libertarian ontological perspective.

The research results do not support Hypothesis 7 as none of models 2, 3, 5 and 6 show any correlation between EBITDA, ROA and strategic-choice-based activities.
Model 1 shows that, in the compatibilist ontological perspective 


\begin{tabular}{|l|l|}
\hline Hypothesis 8 There is a weaker & The comparison between models 2 and 5 indicates that, in the \\
dependence between total assets and \\
organizational performance in a \\
libertarian than in a compatibilist \\
ontological perspective.
\end{tabular}

On the basis of the results obtained, the research hypotheses 1, 2, 5, 6 and 8 are confirmed, indicating that revenue, in the libertarian ontological perspective, depends on strategic-choice-based activities and Total Assets. The results also suggest that, in the compatibilist ontological perspective, revenue depends on strategic-choicebased activities and Total Assets, although the regression coefficient suggests that strategic choice's impact on the dependent variable is rather less pronounced. These findings confirm the validity of the strategic choice determinism framework for the revenue performance variable in the libertarian and compatibilist ontological perspectives.

As far as the research hypotheses 3, 4 and 7 are concerned, the estimates produced no supporting evidence. I.e., either EBITDA or ROA does not depend on strategic-choice-based activities or on determinism when ROA is considered (see Table 8, for further elaboration on the implication of these results).

Considering that revenues are an important performance indicator and can be considered the organizational outcome produced by the use of strategic choice and determinism, companies' revenues' dependence on strategic choice, in the libertarian ontological perspective, and on both strategic choice and determinism in the compatibilist ontological perspective, is sufficient to confirm the validity of the strategic choice/determinism framework for the libertarian and compatibilist ontological perspectives.

The fact that most of the compatibilist NASDAQ sample of utilities and consumers' non-durable goods companies, whose capitalization represents more than $70 \%$ of their industries, do not report R\&D costs on their financial statement, unlike the libertarian technology companies, shows that strategic choice is not the main driver of revenues in the compatibilist ontological perspective, and provides qualitative empirical evidence of the general validity of the strategic choice/determinism framework.

However, the rejection of hypotheses 3,4 and 7, which imply the existence of a relationship between the strategic choice R\&D and SG\&A and the deterministic Total Assets variables and the performance variables of EBITDA and ROA, with the exception of EBITDA, which only depends on Total Assets, was totally unexpected. Having taken into account Zajac et al.'s (2000) results, it was expected that, for the libertarian and compatibilist ontological perspectives, ROA could be somewhat related to the intensity with which either strategic choice or determinism are used in strategic management.

In view of the preceding results, it can be deduced that the study by Zajac et al. (2000), for the deterministic ontological perspective (S\&L industry), the NASDAQ technology industries for the libertarian ontological perspective, and the utilities and non-durable goods industries for the compatibilist ontological perspective, suggests that companies produce revenues, with a different use of strategic choice and determinism according to the ontological perspective in which they operate. However, other important performance indicators, such as EBITDA and ROA, only appear to be related to deterministic independent variables, in the deterministic ontological perspective, while in both the libertarian and compatibilist ontological perspectives, EBITDA depends on Total Assets only, and ROA depends on neither Total Assets nor strategic-choice-based activities nor revenues.

\subsection{Contribution to theory}

On the strength of the theoretical and empirical considerations that have been made up to now, the strategic choice/determinism framework makes the following main contributions to theory:

The framework reduces theoretical fragmentation as it connects the philosophical human agency and strategic management fields, and also justifies the existence of multiple strategic management theories. Although both Marquis and Tilcsik (2013), supporters of imprinting, and Sydow et al. (2009) - advocates of the organizational path theory, see imprinting as the result of a deterministic process, while they look on organizational path dependence as the result of a random event and therefore claim that the two theories are distinct and different, Sydow et al. (2009) concede that "imprinting can explain the path restriction in the preformation phase" (p.686). The above suggests that imprinting constitutes at least one of the possible paths foreseen by organizational path theory, thus suggesting that the two theories should be part of a more holistic theoretical framework, in which imprinting is a mechanism of the organizational path dependence theory.

Figure 8 indicates how authors of different economic theories were all looking at different aspects of the same reality. The fact that the use of free will in human agency and strategic choice in strategic management implies the creation of something new, from which both the human agent and the organization can respectively benefit, highlights a theoretical link between strategic choice and innovation, which, for the libertarian and compatibilist perspectives, becomes the expected outcome of the use of strategic choice. 
The strategic choice determinism framework shows that the resource-based view (RBV) can be considered accurate only for the deterministic ontological perspective, while in the compatibilist or libertarian ontological perspective, performance can only be respectively improved or achieved by adding strategic-choice-based activities to the possession or exploitation of assets. In this context, Zailani et al. (2017)'s study in support of the RBV view, suggests that companies produce performance by resorting to internal logistics resources when in determined market conditions and to the contrary in presence of uncertainty, companies tend to outsource different logistics services.

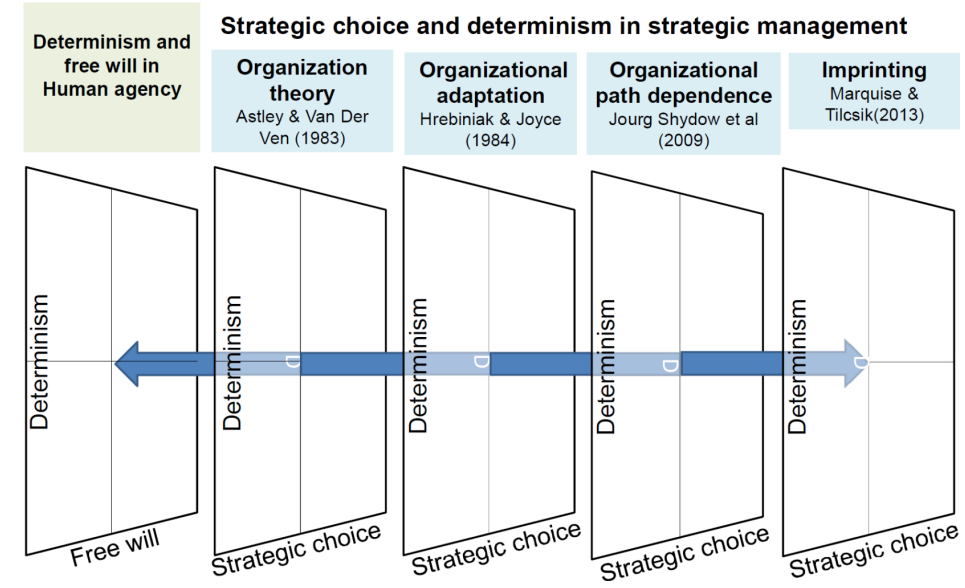

Fig. 8 The links between the fields of human agency and strategic management

In addition, this framework complements and effectively expands Porter's Five Forces approach by showing that there is not only a deterministic approach to planning but also the compatibilist and libertarian ontological perspectives, in which strategic choice and innovation are not a threat but essential to attaining organizational performance.

Porter's framework, in fact, presents innovation and anything new as a threat of substitutes and threat of new entrants, suggesting to managers that they should pursue the status quo by erecting barriers or creating contingencies against innovation and anything new, and discouraging companies from taking advantage of the opportunities generated by the use of strategic choice and innovation.

The strategic choice and determinism framework also supports the existence of the four "paradigms" or clusters of assumptions of functionalist, interpretivist, radical structuralist and radical humanist, identified by Burrell and Morgan (1979, pp.21-25) and Joullié (2018), that frame management and organizational research. Each of these clusters is characterized by a different level of strategic choice that managers use and determinism that they rely on, thus creating theories and planning tools which are performative (allow prediction of future events) within the functionalist and radical structuralist clusters, and are difficult to identify or are undetermined in the postmodern interpretivist and radical humanist clusters.

The contrasting features of these research environments and the limited or uncertain validity of the management theories applicable to each of them brings Joullié (2018) to conclude that the elusiveness of a single and comprehensive theory of management is related to human individuals being free and not abiding by psychological determinism, on which deterministic theories rely, and that the quest for a theory of management should be abandoned in favour of management history, which should serve as a reference for future managers. However, the awareness of the existence of the strategic choice determinism framework provides strength and validity to the theories and planning tools which are valid within each non-exclusive perspective of the framework. Managers can therefore rely upon these planning tools as long as they take into account each theory-specific environmental-validity boundary.

The strategic choice determinism framework helps to explain the existence of organizational contrasting strategies such as long-term versus short-term, innovation versus tradition, and stability versus change as shown by Karhu and Ritala (2020). These apparently irreconcilable organizational strategies, whose contrast can be related to a different use of strategic choice and determinism, are, in reality, organizational conditions whose existence is predicted by the framework. In fact, empirical data shows that managers use different levels of strategic choice or determinism to produce performance, according to the perspective in which their respective organizations operate. 


\subsection{Contribution to practice}

The practical implications of the empirical validity of the strategic choice determinism framework could be of paramount importance for real-life companies as the preceding analysis suggests the following:

- The ontological perspectives the framework describes apply to different aspects of organizational life, thus connecting real-life decision making to the continuing and live philosophical debate about free will and determinism.

- The strategic choice determinism framework clearly shows the link between strategic choice and innovation, and highlights its importance in each of the ontological perspectives, according to how much strategic choice is available to management. The use that management makes of innovation can be revealed by how much a company spends on $R \& D$ and on the related marketing activities used to promote it. As shown by Ou Yang et al. (2019) the greater the market uncertainty the fastest managers bring new products to market.

- The strategic choice/determinism framework can help management, at a practical level, by indicating to companies what use they should make of strategic choice and determinism in order to produce organizational performance, according to the ontological perspective in which they operate. This consideration helps management to make the most effective choice between the contrasting business strategies of long-term versus short-term, innovation versus tradition, and stability versus change presented by (Karhu and Ritala, 2020).

- Organizational path dependence and imprinting theories can help to map the part of the path as well as perspective in which a company is located, and in which direction it is going, thus providing practical suggestions drawn from theory on how to reach strategic objectives.

- If we consider that a company, operating in the deterministic perspective by knowing and applying the laws and rules of the environment, can rely on expected performance, and similarly that a company which operates in the libertarian perspective knows it has to use strategic choice in order to produce performance, we can understand how the strategic choice determinism framework can help to reduce uncertainty in planning.

On the whole, one of the main features of the strategic choice determinism framework is that it highlights the importance of strategic choice and its importance in planning, as opposed to all the major planning theories (i.e. contingency theory, the RBV, Porter's Five Forces, etc.) which only focus on the deterministic aspects of planning. The strategic choice determinism framework points out, in a way no other theory has done before, and in addition to the traditionally known deterministic approach to planning, the importance of strategic choice, as the framework enables us to position each organization in a particular perspective, by identifying how much it relies either on strategic choice and/or on determinism.

\section{Conclusions}

In this paper, we argue that there is a link between the human agency variables of free will and determinism, and the strategic management variables of strategic choice and socio-economic determinism, and that each pair of variables creates a space or framework, which identifies the four human agency ontological perspectives of determinism, hard incompatibilism, libertarianism and compatibilism. We call the framework, identified by strategic choice and socio-economic determinism, the strategic choice determinism framework.

We then provide evidence of the framework's real-life existence, awareness of which can also help management to both identify the most appropriate economic theories, which suggest the use of different amounts of strategic choice and determinism, that apply to each environment, in order to produce performance, and draw useful conclusions rooted in the philosophical context of human agency, thanks to the link that connects it to strategic management.

At a theoretical level, the framework reduces theoretical fragmentation and helps to justify the existence of, and to frame, existing economic theories according to the amount of strategic choice and socio-economic determinism upon which they rely within each of the framework's perspectives. This consideration explains the elusiveness of the search for a single theory of management and suggests that existing management theories can be reliably used within the boundaries of the environment in which they are valid.

\subsection{Limitations and future directions}

The research results presented in this paper may be affected by the following limitations:

a) Possible partiality of variables as the examined strategic choice and determinism independent variables of R\&D, SG\&A and Total Assets may only be some of the variables which indicate the use of strategic choice and determinism within a company. 
b) Possible incoherence of variables since SG\&A was used as a proxy for strategic choice because it usually includes the strategic-choice-indicative activities of marketing and advertising. Some companies, however, may have posted marketing and advertising costs in their financial statements separately from SG\&A and included in it many other expenses unrelated to strategic choice, which could override strategic-choice-based activities.

c) Some companies might put strategic-choice-based activities costs in different company statement entries, thereby possibly creating unreliable results.

d) The compatibilist and libertarian company samples were observed over a limited time span of four years. Over a longer time period, these samples could produce different results.

e) The limited number of MEGA companies, with a capitalization greater than 10 billion USD, which constitute the samples studied, may reduce the representativeness of the industry samples, creating the risk of inconsistent results.

Some possible directions for future research could include the investigation of the relationship between financial statement factors, such as cost of sales, taxes and capital structure as shown by Hoffmann (2014), which may vary from company to company, in the deterministic, libertarian and compatibilist industries, and performance. Future research could also enhance our knowledge of the role that strategic choice and determinism play in determining organizations' internal environments, thus affecting, as the research has shown, performance indicators. Future research could also investigate a more diverse sample of companies from platforms other than the NASDAQ.

\section{References}

Astley WG, Van de Ven AH (1983). Central perspectives and debates in organization theory. Admin Sci Q 28(2): 245-273

Bhaskar R (1989). Reclaiming reality: A Critical Realist Introduction to Contemporary Philosophy. London: Verso

Bourdieu P (1988) Homo Academicus. Stanford: Stanford Academic Press

Bourgeois LJ (1984) Strategic management and determinism. Acad Manag Rev 9: 586-596

Burrell G, Morgan, G (1979). Sociological Paradigms and Organisational Analysis. Ashgate, London, pp. 21-25

Bushman RM, Indjejikian RJ, Smith A (1996). CEO Compensation: The role of individual performance Evaluation. J Accoun Econ 21: 161-193

Child J (1972) Organizational structure environment and performance. Sociol 2:1-22

Christensen CM, Raynor ME. (2003) The innovator's solution: creating and sustaining successful growth. Harvard Business School Press, Boston

Croissant Y, Millo G (2008) Panel data econometrics in R: The plm package. J Stat Softw 27:14-32

De Rond M, Thietart RA (2007) Choice, chance, and inevitability in strategy. Strateg Manag J 28:535-551

Donaldson L (1987) Strategy and structural adjustment to regain fit and performance: in defence of contingency theory. J Manag Stud 24:1-24

Donaldson L (1997) A positivist alternative to the structure-action approach. Organ Stud 18(1): 77-92

Donaldson L (2005) Following the scientific method: How I became a committed functionalist and positivist. Organ Stud 26:1071-1088

Emirbayer M, Mische A (1998) What is agency? Amer J Sociol, 103:962-1023

Finkelstein S, Hambrick DC (1990) Top-Management-Team tenure and organizational outcomes: The moderating role of managerial discretion. Admin Sci Q 35:480-503

Fitza MA (2013) The use of variance decomposition in the investigation of CEO effects: how large must CEO effect be to rule out chance? Strateg Manag J 35:1839-1852

Fitza MA (2017) How much do CEOs really matter? Reaffirming that the CEO effect is mostly due to chance. Strateg Manag J 38:802-811

Fontana R, Nuvolari A, Shimizu H, Vezzulli A (2012) Schumpeterian patterns of innovation and the sources of breakthrough inventions: evidence from a data-set of R\&D awards. J Evolut Econ 22:785-810

Giddens A (1984) The constitution of society: outline of the theory of structuration. University of California Press

Gomez-Mejia LR, Tosi H, Hikkin T (1987) Managerial control, Performance and executive compensation. Acad Manag J 30:51-70

Gomez-Mejia LR, McCann JE (1988) Measuring internal strategic choice decisions and their linkages to the reward structure: a case study in a high technology firm. Intl J Manpower, 9:28-42

Gupta AK (1987) SBU strategies, corporate-SBU, and SBU effectiveness in strategy implementation. Acad Manag J 30:477-500

Haji I (2000) Indeterminism, explanation, and luck. J Eth 4:211-235 
Harland PE, Uddin Z, Laudien S (2020) Product platforms as a lever of competitive advantage on a companywide level: a resource management perspective. Rev Manag Sci 14:137-158. https://doi.org/10.1007/s11846-018-0289-9

Haynes K, Hillman A (2010) The effect of board capital and CEO power on strategic change. Strateg Manag J 31:1145-1163

Heisenberg W (1926) Quantenmechanik. Die Naturwissenschaften, 14:899-894

Hoffmann PS (2014) Internal corporate governance mechanisms as drivers of firm value: panel data evidence for Chilean firms. Rev Manag Sci 8:575-604. https://doi.org/10.1007/s11846-013-0115-3

Hrebiniak LG, Joyce WF (1985) Organizational adaptation: Strategic choice and environmental determinism. Admin Sci Q 30:336

ISO 31000 (2009) Risk management - Principles and guidelines. International Organization for Standardization.

Ittner CD, Larcker DF, Randall T (2003) Performance Implications of Strategic Performance Measurement in Financial Service Firms. Account Organiz Soc 28:715-741

Jost P (2013) An economic theory of leadership styles. Rev Manag Sci 7:365-391. https://doi.org/10.1007/s11846-012-0081-1

Joullié JE (2018) Management without theory for the twenty-first century. J Manag Hist 24: 377-395

Kane R (1999) On free will, responsibility and indeterminism: Responses to Clarke, Haji, and Mele. Philosophical Explorations, 2:105-121

Karhu ., Ritala P (2020) The multiple faces of tension: dualities in decision-making., Rev Manag Sci 14:485-518. https://doi.org/10.1007/s11846-018-0298-8

Leca B, Naccache P (2006) A critical realist approach to institutional entrepreneurship. Organization 13:627-651

Malerba F (2005) Sectoral systems: how and why innovation differs across sectors. The Oxford handbook of innovation. Oxford University Press, Oxford, pp. 380-406

Marquis C, Tilcsik A (2013) Imprinting: Toward a multilevel theory. Acad Manag Annals 7:195-245

Mellahi K, Wilkinson A (2004) Organizational failure: a critique of recent research and a proposed integrative framework. Int J Manag Rev 5-6:21-41

Montanari J R (1979) Strategic choice: A theoretical analysis. J Manag Stud 16:202

Ou Yang Z, Cheng P, Liu Y (2019) The role of product line breadth, product pre-entry experience, and market uncertainty in explaining followers' speed of feature entry. Rev Manag Sci https://doi.org/10.1007/s11846-019-00328-5

Pucheta-Martínez MC, Gallego-Álvarez I (2019) Do board characteristics drive firm performance? An international perspective. Rev Manag Sci. https://doi.org/10.1007/s11846-019-00330-x

Penrose ET (1959) The theory of the growth of the firm. John Wiley, New York

Porter ME (1981) The contributions of industrial organization to strategic management. Acad of Manag Rev 6:609-620

Sarasvathy SD (2001) Causation and effectuation: Toward a theoretical shift from economic inevitability to entrepreneurial contingency. Acad Manag Rev 26:243-263

Schreyögg G (1980) Contingency and choice in organization theory. Organiz Stud 1:305-326

Schumpeter J (1911) The Theory of Economic Development. Harvard University Press, Cambridge

Schumpeter J (1942) Capitalism, Socialism and Democracy. The Theory of Organizations. Heinemann, London.

Silverman D (1970) The Theory of Organizations. Heinemann, London

Simons R (1991) How new top managers use control systems as levers of strategic renewal. Strateg Manag J 15:169-189

Spector P, Brannick M (2013) Methodological urban legends: The misuse of statistical control variables. Orga Res Meth 14:287-305

Stanford Encyclopedia of Philosophy(a). AccessedApril 6 ${ }^{\text {th }}$ 2018.http://plato.stanford.edu/entries/compatibilism/

Stanford Encyclopedia of Philosophy(b), Accessed May $8^{\text {th }} 2018$ https://plato.stanford.edu/archives/win2009/entries/determinism-causal/

Shwairef A, Amran A, Iranmanesh M, Ahmad N (2019) The mediating effect of strategic posture on corporate governance and environmental reporting. Rev Manag Sci., https://doi.org/10.1007/s11846-019-00343-6

Sydow J, Schreyögg G, Koch J (2009) Organizational path dependence: Opening the black box. Acad Manag Rev 34:689-709

Thompson JD (1967) Organizations in action. McGraw-Hill, New York

Tversky A Kahneman D (1974) Judgment under uncertainty: Heuristics and biases. Sci 185:1124-1131

Varadarajan PR, Clark T, Pride WM (1992) Controlling the uncontrollable: managing your Market environment. Sloan Manag Rev 33:39-53

Voigt K (2011) Special topic: strategic innovations. Rev Manag Sci 5:263. https://doi.org/10.1007/s11846-0110070-9

Yoon W, Kim SJ, Song J (2016). Top management team characteristics and organizational creativity. Rev Manag Sci 10:757-779. https://doi.org/10.1007/s11846-015-0175-7 
Wack P (1985) Scenario uncharted waters ahead. Harv Bus Rev 9-10:73-89

Weiner N, Mahoney, TA (1981) A model of corporate performance as a function of environmental, organizational and leadership influences. Acad Manag J 24:453-470

Werner S, Tosi HL (1995) Other People's Money: The effects of ownership on compensation strategy and managerial pay. Acad Manag J 38:1672-1681

Werner S, Tosi HL, Gomez-Mejia L (2005) Organizational governance and employee pay: how ownership structure affects the firm's compensation strategy. Strat Manag J 26:377-384

Whittington R (1988) Environmental structure and theories of strategic choice. J Manag Stud 25:521-536

Whittington R (2010) Giddens, structuration theory and strategy as practice. Cambridge handbook of strategy as practice. Cambridge: Cambridge University Press, pp 109-126

Wooldridge J (2002) Econometric Analysis of Cross-Section and Panel Data. Cambridge (MA): MIT Press

Zailani S, Shaharudin MR, Razmi K, Iranmanesh M (2017) Influential factors and performance of logistics outsourcing practices: an evidence of Malaysian companies. Rev Manag Sci 11:53-93. https://doi.org/10.1007/s11846-015-0180-x

Zajac EJ, Kraatz MS, Bresser RKF (2000) Modelling the dynamics of strategic fit: a normative approach to strategic change. Strateg Manag J 21:429-453 


\section{Appendix A}

Table 1 Dependent and independent variables' descriptive statistics)

\begin{tabular}{|c|c|c|c|c|c|c|}
\hline & \multicolumn{7}{|c|}{ Compatibilist perspective } \\
\hline & Revenue & EBITA & ROA & R\&D & SG\&A & $\begin{array}{c}\text { Total } \\
\text { Assets }\end{array}$ \\
\hline Mean & 18821 & 4176 & 2.338 & 2163 & 4003.4 & 34369 \\
\hline St.dev. & 25135.02 & 6889.63 & 20.92 & 13121.12 & 7843.58 & 49978.52 \\
\hline Min & 0 & -3219 & -237.6 & 0 & 0 & 0 \\
\hline Max & 132447 & 50112 & 37.1 & 127000 & 46869 & 292829 \\
\hline & Revenue & EBITA & ROA & R\&D & SG\&A & $\begin{array}{c}\text { Total } \\
\text { Assets }\end{array}$ \\
\hline & 16256 & 4328.9 & 6.816 & 1482.8 & 2612 & 24376 \\
\hline Mean & 30374.67 & 9228.57 & 11.24 & 2236.12 & 4557.911 & 39101.11 \\
\hline St.dev. & 24 & -6838 & -58 & 4 & 6 & 0 \\
\hline Min & 182795 & 61429 & 36 & 11381 & 22680 & 231839 \\
\hline Max & \multicolumn{7}{|c|}{ Libertarian perspective } \\
\hline
\end{tabular}

